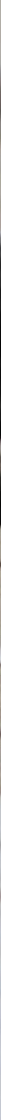

Monitoring van gewone en grijze zeehonden in de Nederlandse Waddenzee, 2002-2017 

Monitoring van gewone en grijze zeehonden in de Nederlandse Waddenzee, 2002-2017 
Dit Technical report is gemaakt conform het Kwaliteitsmanagementsysteem (KMS) van de unit Wettelijke Onderzoekstaken Natuur \& Milieu, onderdeel van Wageningen University \& Research.

De WOT Natuur \& Milieu voert wettelijke onderzoekstaken uit op het beleidsterrein natuur en milieu. Deze taken worden uitgevoerd om een wettelijke verantwoordelijkheid van de minister van Landbouw, Natuur en Voedselkwaliteit (LNV) te ondersteunen. De WOT Natuur \& Milieu werkt aan producten van het Planbureau voor de Leefomgeving, zoals de Balans van de Leefomgeving en de Natuurverkenning. Verder brengen we voor het ministerie van LNV adviezen uit over (toelating van) meststoffen en bestrijdingsmiddelen, en zorgen we voor informatie voor Europese rapportageverplichtingen over biodiversiteit.

De reeks 'WOt-technical reports' bevat onderzoeksresultaten van projecten die kennisorganisaties voor de unit Wettelijke Onderzoekstaken Natuur \& Milieu hebben uitgevoerd.

WOt-technical report 104 is het resultaat van een onderzoeksopdracht van en gefinancierd door het Ministerie van Landbouw, Natuur en Voedselkwaliteit (LNV). 


\section{Monitoring van gewone en grijze zeehonden in de Nederlandse Waddenzee, 2002-2017}

J.S.M. Cremer, S.M.J.M. Brasseur, A. Meijboom, J. Schop \& J.P. Verdaat 


\section{Referaat}

Cremer, J.S.M., S.M.J.M. Brasseur., A. Meijboom, J. Schop \& J.P. Verdaat (2017). Monitoring van gewone en grijze zeehonden in de Nederlandse Waddenzee, 2002-2017. Wageningen, Wettelijke Onderzoekstaken Natuur \& Milieu, WUR. WOt-technical report 104 (WMR-rapport: C095/17). 40 blz.; 11 fig.; 10 tab.; 23 ref.

De jaarlijkse monitoring van de gewone (Phoca vitulina) en de grijze zeehonden (Halichoerus grypus) in de Waddenzee dient ter ondersteuning van het (internationaal) beheer van en het beleid voor de zeehondenpopulaties. Deze tellingen voert Wageningen Marine Research (WMR) sinds 1960 uit in opdracht van het ministerie van Landbouw, Natuur en Voedselkwaliteit. Uit de resultaten blijkt dat de groei van de gewone zeehondenpopulatie afneemt, maar dat de getelde aantallen grijze zeehonden nog steeds toenemen. Binnen het Nederlandse deel van de Waddenzee zijn er trendverschillen tussen de deelgebieden te constateren. Dat geldt voor beide zeehondensoorten. Ook is er verschil in ligplaatskeuze tijdens de reproductie en de verharingsperiode. Nader onderzoek moet uitwijzen welke factoren deze aantallen en ligplaatskeuze beïnvloeden en hoe ze bijdragen aan de omvang van de populatie.

Trefwoorden: gewone zeehond, grijze zeehond, Waddenzee, populatieontwikkeling, monitoring.

\section{Abstract}

Cremer, J.S.M., S.M.J.M. Brasseur, A. Meijboom, J. Schop \& J.P. Verdaat (2017). Monitoring harbour and grey seals in the Dutch Wadden Sea, 2002-2017. Wageningen, Statutory Research Tasks Unit for Nature \& the Environment (WOT Natuur \& Milieu, WUR), WOt-technical report 104. (WMR-rapport: C095/17) 40 p.; 11 Figs; 10 Tabs; 23 Refs.

Harbour seal (Phoca vitulina) and grey seal (Halichoerus grypus) in the Wadden Sea are surveyed each year to support the international management of and policies for both populations. This annual census has been carried out for the Ministry of Agriculture, Nature and Food Quality by Wageningen Marine Research (WMR) since 1960 . The results show that the growth in the harbour seal population is flattening off while the counted numbers of grey seal are still rising. Differences in the trend in numbers counted between sub-areas of the Dutch Wadden Sea have been observed for both seal species. The preferred haul-out sites also differ between the breeding season and moulting period. Further research will be needed to show which factors influence numbers and choice of haul-out site, and how these factors affect population size.

Keywords: harbour seal, grey seal, Wadden Sea, population trend, survey

Foto omslag: Hans Verdaat

\section{(C) 2017 Wageningen Marine Research}

Ankerstraat 27, 1781 AG Den Helder

Tel: (0317) 480900; e-mail: secretariaat.marine-research@wur.nl

De reeks WOt-technical reports is een uitgave van de unit Wettelijke Onderzoekstaken Natuur \& Milieu, onderdeel van Wageningen University \& Research. Dit report is verkrijgbaar bij het secretariaat. De publicatie is ook te downloaden via www.wur.nl/wotnatuurenmilieu.

Wettelijke Onderzoekstaken Natuur \& Milieu, Postbus 47, 6700 AA Wageningen

Tel: (0317) 4854 71; e-mail: info.wnm@wur.nl; Internet: www.wur.nl/wotnatuurenmilieu.

Alle rechten voorbehouden. Niets uit deze uitgave mag worden verveelvoudigd en/of openbaar gemaakt door middel van druk, fotokopie, microfilm of op welke andere wijze ook zonder voorafgaande schriftelijke toestemming van de uitgever. De uitgever aanvaardt geen aansprakelijkheid voor eventuele schade voortvloeiend uit het gebruik van de resultaten van dit onderzoek of de toepassing van de adviezen. 


\section{Woord vooraf}

Dit technical report beschrijft de resultaten van de tellingen van gewone en grijze zeehonden in de Nederlandse Waddenzee. Deze monitoring vindt plaats in het kader van de Wettelijke

Onderzoekstaken Natuur \& Milieu, in navolging van de EU-Habitatrichtlijn en de trilaterale afspraken over de Waddenzee en, voor de gewone zeehond, ook in het kader van de 'Agreement' onder de Conventie van Bonn (CMS). Het rapport omvat de aantalsontwikkeling van deze beide soorten van 2002 tot 2017.

Jenny Cremer, Sophie Brasseur, André Meijboom, Jessica Schop \& Hans Verdaat 



\section{Inhoud}

Woord vooraf

Samenvatting

Summary

$1 \quad$ Inleiding

13

1.1 Zeehonden in Nederland 13

$\begin{array}{lll}1.2 & \text { Tellingen } & 14\end{array}$

$\begin{array}{lll}1.3 & \text { Doel van dit rapport } & 15\end{array}$

2 Methode $r$

3 Resultaten $r$

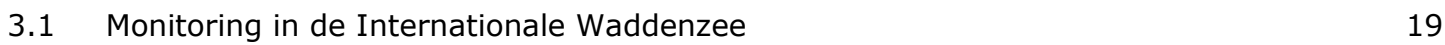

$\begin{array}{ll}3.1 .1 \text { Gewone zeehond } & 19\end{array}$

$\begin{array}{ll}3.1 .2 \text { Grijze zeehond } & 20\end{array}$

$\begin{array}{lll}3.2 & \text { Gebiedsgebruik } & 23\end{array}$

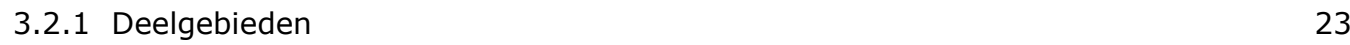

3.2.2 Gewone zeehond $\quad 23$

$\begin{array}{ll}3.2 .3 \text { Grijze zeehond } & 25\end{array}$

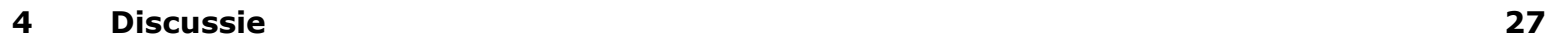

$\begin{array}{ll}4.1 .1 & \text { Tellingen }\end{array}$

$\begin{array}{ll}4.1 .2 \text { Ligplaatsen } & 27\end{array}$

$\begin{array}{ll}4.1 .3 \text { Draagkracht } & 28\end{array}$

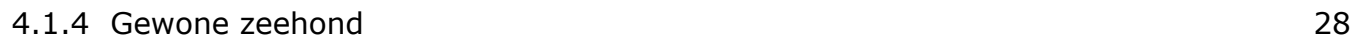

$\begin{array}{ll}4.1 .5 \text { Grijze zeehond } & 29\end{array}$

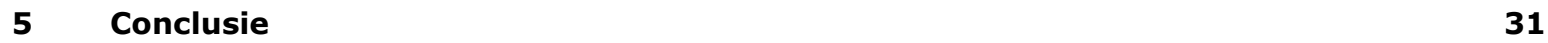

$\begin{array}{ll}\text { Literatuur } & 33\end{array}$

$\begin{array}{lr}\text { Verantwoording } & 35\end{array}$ 



\title{
Samenvatting
}

\author{
Monitoring \\ De monitoring van de gewone zeehond (Phoca vitulina) en de grijze zeehond (Halichoerus grypus) \\ wordt uitgevoerd om het beheer van en het beleid voor beide zeehondenpopulaties te ondersteunen. \\ Deze monitoring wordt uitgevoerd in navolging van de EU-Habitatrichtlijn en de trilaterale afspraken \\ over de Waddenzee en, voor de gewone zeehond, ook in het kader van de 'Agreement' onder de \\ Conventie van Bonn (CMS). Daartoe worden de zeehonden op de zandplaten in de Waddenzee jaarlijks \\ geteld. Deze tellingen voert Wageningen Marine Research (WMR) uit in opdracht van het ministerie \\ van Landbouw, Natuur en Voedselkwaliteit en zijn onderdeel van de Wettelijke Onderzoekstaken \\ Natuur en Milieu.
}

Om de groei van de populaties te bepalen, worden de maximale aantallen volwassen zeehonden in de verharingsperiode vastgesteld, voor gewone en grijze zeehonden respectievelijk in augustus en in maart/april. De pup-productie wordt bepaald aan de hand van het getelde aantal pups gedurende de zoogperiode. Bij gewone zeehonden wordt de pup-productie in juni/juli bepaald, voor de grijze zeehonden is dit in december/januari. WMR en haar voorgangers tellen al sinds 1960 de gewone zeehonden in de Nederlandse Waddenzee, in 2007 zijn daar de tellingen voor de grijze zeehonden bijgekomen.

\section{Gewone zeehonden}

Uit de tellingen van de gewone zeehonden blijkt dat de getelde aantallen de laatste jaren weinig meer toenemen. In 2017 zijn er in de Nederlandse Waddenzee tijdens de verharing maximaal 8427 gewone zeehonden geteld. De Trilateral Seal Expert Group (TSEG) suggereert in haar jaarlijkse rapportages (Galatius et al., 2016; 2017) dat de draagkracht van de Waddenzee voor deze soort benaderd wordt. De nog steeds toenemende aantallen pups lijken daar vooralsnog mee in tegenspraak. Het is nog onduidelijk welke factoren de hoogte van de draagkracht bepalen: zowel maatschappelijke factoren (bijv. recreatie, scheepvaart, en dergelijke) als fysische en biologische factoren (bijv. geomorfologische veranderingen, voedselbeschikbaarheid) kunnen hier aan bijdragen.

Tussen de deelgebieden van de Nederlandse Waddenzee zijn verschillen te constateren. In een aantal gebieden, bijvoorbeeld tussen Vlieland en Terschelling (deelgebied 03), nemen de aantallen niet meer toe, terwijl in het gebied rond de Noorderhaaks en het Balgzand ze nog wel stijgen. Eerder genoemde factoren zouden ook hier van invloed kunnen zijn op het aantalsverloop.

Uit de vergelijking van de tellingen van de gewone zeehond tijdens de verharingsperiode en de reproductieperiode blijkt dat tijdens de verharing de westelijke Waddenzee meer in trek is, terwijl het oostelijke deel tijdens de reproductieperiode populair is. Zeehonden lijken in de reproductieperiode andere eisen te stellen aan hun ligplaatsgebieden dan tijdens de verharingsperiode. Kennis omtrent die verschillende eisen zou het instellen van beschermende maatregelen kunnen verbeteren en effectiever kunnen maken.

\section{Grijze zeehonden}

Uit de tellingen van de grijze zeehonden blijkt dat de soort blijft toenemen in de Waddenzee. De meeste dieren worden in het Nederlandse deel geteld, maar de aantallen nemen ook toe in de andere landen. Ook het aantal getelde pups groeit. In 2017 zijn er 4045 grijze zeehonden geteld in de Nederlandse Waddenzee.

De meeste grijze zeehonden (zowel tijdens de verharing als tijdens de reproductie) worden in het gebied tussen Vlieland en Terschelling geteld, echter ook van deze soort nemen de aantallen daar niet meer toe. Op de Noorderhaaks (gebied 01) daarentegen nemen de grijze zeehonden de laatste jaren wel toe. 
De relatie tussen het aantal getelde pups en het aantal getelde dieren tijdens de verharing is minder sterk dan bij de gewone zeehond. Het groeiende aantal grijze zeehonden kan niet alleen uit het toenemende aantal pups worden verklaard: ook migratie van zeehonden tussen de Waddenzee en het Verenigd Koninkrijk speelt een rol, zo blijkt uit eerder onderzoek. De grijze zeehonden uit de Waddenzee en het Verenigd Koninkrijk behoren tot dezelfde populatie. 


\title{
Summary
}

\author{
Monitoring \\ The harbour seal (Phoca vitulina) and grey seal (Halichoerus grypus) in the Wadden Sea are surveyed \\ each year to support the management of and policies for both populations. This monitoring is carried \\ out pursuant to the EU Habitats Directive and the trilateral agreements on the Wadden Sea and, for \\ the harbour seal, as part of the 'Agreement' under the Bonn Convention (CMS). Each year the seals on \\ the sand banks in the Wadden Sea are counted. These annual counts are carried out for the Ministry \\ of Agriculture, Nature and Food Quality by Wageningen Marine Research (WMR) and are part of the \\ Statutory Research Tasks for Nature and the Environment.
}

To calculate the growth in the populations, the maximum numbers of adult seals are assessed in the moulting period - in August for the harbour seal and in April/May for the grey seal. Pup production is assessed from the number of pups counted during the suckling period. Harbour seal pup production is assessed in June/July and grey seal pup production in December/January. WMR and its predecessors have been counting seals in the Dutch Wadden Sea since 1960; the surveys of grey seal began in 2007.

\section{Harbour seal}

The counted numbers of harbour seal have not increased much in recent years. In 2017 the maximum number of harbour seals counted in the Dutch Wadden Sea during the moulting period was 8,427 . In its annual reports the Trilateral Seal Expert Group (TSEG) suggests that the carrying capacity of the Wadden Sea for this species has almost been reached (Galatius et al., 2016; 2017). However, until now this ap-pears to be contradicted by the increasing number of pups. It is still not clear which factors determine the size of the carrying capacity: both human activities (e.g. recreation, shipping and such like) and physical and biological factors (e.g. geomorphological changes, food availability) could be involved.

Differences have been observed between the sub-areas of the Dutch Wadden Sea. In a number of areas, for example between the islands of Vlieland and Terschelling (sub-area 03), the counted numbers are no longer increasing, but numbers continue to rise in the area around the small uninhabited island of Noorderhaaks and the Balgzand tidal flats. The factors mentioned above could also be affecting the trend in counted numbers observed here.

A comparison of the counts of harbour seal during the moulting period and during the breeding season shows that the western Wadden Sea is preferred during the moulting period and the eastern Wadden Sea is more popular during the breeding season. Seals appear to make different demands on haul-out sites during the breeding season than during the moulting period. Knowledge of these demands could improve the establishment and effectiveness of protective measures.

\section{Grey seal}

The grey seal counts indicate that the counted numbers of this species in the Wadden Sea continues to increase. Most of the animals are surveyed in the Dutch area of the Wadden Sea, but numbers in the other countries are also increasing. The number of counted pups is also increasing. In 2017 the number of grey seals counted in the Dutch Wadden Sea was 4,045.

Most grey seals were found in the area between the islands of Vlieland and Terschelling (both during the moulting period and the breeding season), but the counted numbers of this species is also no longer increasing in this area. In contrast, the counted numbers of grey seal on Noorderhaaks (subarea 01 ) has been increasing in recent years.

The relation between the number of counted pups and the number of counted animals during the moulting period is not as strong as for the harbour seal. The growth in grey seal numbers cannot be explained by the increasing number of pups alone: previous research has shown that migration of grey seals between the Wadden Sea and the United Kingdom also plays a role. The grey seals in the Wadden Sea and the United Kingdom belong to the same population. 


\section{$1 \quad$ Inleiding}

\subsection{Zeehonden in Nederland}

In de Nederlandse wateren leven twee soorten zeehonden: de gewone zeehond (Phoca vitulina) en de grijze zeehond (Halichoerus grypus). De twee soorten behoren binnen de orde Carnivora tot de familie van de Phocidea, of 'echte' zeehonden. Ze leven en foerageren op zee, maar komen regelmatig aan land, in Nederland vooral op de wadplaten in de Waddenzee en een relatief klein aantal op zandplaten en slikken in de Delta. Hoe vaak en hoe lang de dieren op de kant komen varieert sterk per individu, waardoor de aantallen op de kant ook sterk kunnen verschillen. Echter in de voortplantingstijd en tijdens de verharingsperiode zijn de dieren meer genoodzaakt aan land te komen, waardoor in die periodes een bijna vaste proportie van de populatie te zien is. De tellingen worden daarom in deze periodes gehouden. De verspreiding en aantallen van beide soorten zijn veranderd in de loop van de tijd. Van beide soorten neemt het aantal toe in de laatste decennia terwijl ze herstelden van zeer zware overbejaging, gevolgd door periodes van vervuiling en voor de gewone zeehonden bovendien virusziektes.

Sinds 1960 zijn er steeds betrouwbaarder tellingen van zeehonden in de Nederlandse Waddenzee gekomen. Werden de zeehonden in het begin nog vanuit een boot geteld, tegenwoordig wordt vanuit een vliegtuig met GPS en camera gewerkt (zie Hoofdstuk 2, Methode).

Van de aantallen uit de periode vóór 1960 zijn schattingen gemaakt op basis van onder andere jachtgegevens (Reijnders, 1992). Het verloop van de geschatte en getelde aantallen van de zeehonden sinds het begin van de vorige eeuw wordt, zowel van de grijze als van de gewone zeehond in de Nederlandse Waddenzee, in figuur 1 weergegeven. Na een dieptepunt in de jaren zeventig en tachtig herstelden de aantallen zich weer door stopzetting van de jacht en het verbod op het gebruik van PCB's.

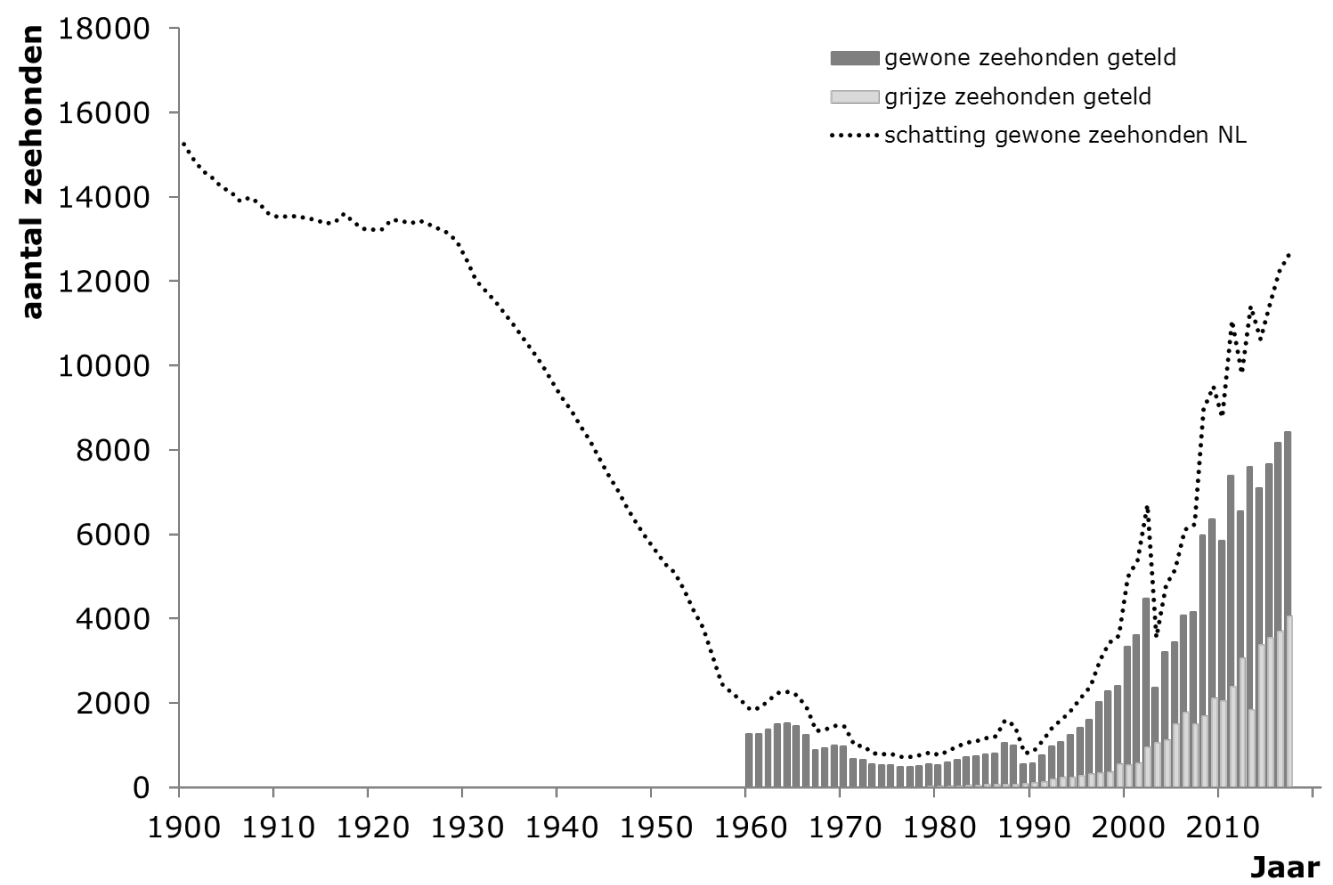

Figuur 1. Aantalsverloop van getelde gewone (donkergrijze balken) en grijze zeehonden (lichtgrijze balken) in de Nederlandse Waddenzee in de verharingsperiode tussen 1900 en 2017. Vanaf 1960 worden jaarlijkse tellingen uitgevoerd. Stippellijn: geschatte totaal aantallen gewone zeehonden in Nederland. Gegevens van voor 1960 zijn berekend aan de hand van jachtgegevens (Reijnders, 1992). Voor de grijze zeehond is geen correctiefactor bekend en kan de populatie niet geschat worden. 
Het aantal gewone zeehonden in de Nederlandse Waddenzee was in de vorige eeuw gedaald van naar schatting 15.000 dieren in 1900 naar amper 1000 dieren in de jaren zeventig. Sluiting van de jacht in 1960 in Nederland heeft de populatie niet doen herstellen, evenmin als de daaropvolgende sluiting in Duitsland en Denemarken (Brasseur, 2017). Vooral de aanwezigheid van PCB's in hun voedsel hield de populatie klein (Reijnders, 1986). Pas na de ban op PCB's in de jaren tachtig begon de Internationale Waddenzeepopulatie aan een herstel. Twee Phocine Distemper Virus (PDV)-epidemieën (in 1988 en 2002) hebben daarna de populatie gehalveerd (Reijnders et al., 2003; Härkönen et al., 2006). De populatie heeft zich echter goed hersteld na beide epidemieën en sinds de laatste in 2002 zijn de aantallen weer gegroeid.

Omdat er continu uitwisseling is van gewone zeehonden naar andere landen, worden de gewone zeehonden die gebruik maken van de internationale Waddenzee als één populatie beschouwd. Er zijn sterke aanwijzingen dat de dieren in het Deltagebied ook tot deze populatie behoren.

Binnen de internationale Waddenzee komen de meeste grijze zeehonden voor in het Nederlandse deel van de Waddenzee, maar ze bewegen zoveel tussen de Waddenlanden en het Verenigd Koninkrijk en in mindere mate andere aangrenzende gebieden (Deltagebied en Frankrijk) dat men niet van een duidelijk begrensde populatie kan spreken.

Beide soorten zijn beschermd onder de EU Habitatrichtlijn (Appendix II). Bovendien zijn de gewone zeehonden binnen de Conventie van Migratory Species (CMS) van Bonn beschermd. Daarnaast hebben de drie Waddenzeelanden Denemarken, Duitsland en Nederland afspraken over het beheer van de Waddenzee, waaronder de zeehonden ('Trilateral Agreement').

De drie afspraken (EU-habitat, CMS en de Trilateral Agreement) worden voor de zeehonden verwezenlijkt in een beheersplan in de vorm van het Seal Management Plan (SMP)

(http://www.waddensea-secretariat.org/sites/default/files/downloads/smp_2012-2016_final.pdf). Dit plan voor Nederland, Duitsland en Denemarken omvat doelstellingen en acties over de bescherming, onderzoek en monitoring en omvat ook bijvoorbeeld het toezicht op beschermende maatregelen en de publieksvoorlichting. De Trilateral Seal Expert Group (TSEG) stelt het plan elke vijf jaar op en ziet er tevens op toe dat het wordt uitgevoerd. De monitoring wordt ook jaarlijks door TSEG gecoördineerd, met ondersteuning van het Common Wadden Sea Secretariat. Deze laatste verzamelt monitoringsgegevens in een database genaamd TMAP. Het SMP is gericht op de internationale populatie gewone zeehonden in de Waddenzee, maar is, als gevolg van de recente toename, uitgebreid met de grijze zeehonden in de Waddenzee.

\subsection{Tellingen}

In navolging van het SMP voor de gewone en de grijze zeehond worden zeehonden in de Waddenzee jaarlijks geteld. Deze tellingen voert Wageningen Marine Research (WMR) uit in opdracht van het ministerie van Landbouw, Natuur en Voedselkwaliteit. Het monitoringsprogramma voor het aantal gewone zeehonden wordt sinds 1959 uitgevoerd. Vanaf 2001 worden ook voor de grijze zeehonden monitoringsvluchten uitgevoerd. Vóór die tijd werden de aantallen grijze zeehonden, die zich op één zandplaat ten westen van Terschelling concentreerden, per boot geteld (Reijnders et al., 1995). De tellingen worden uitgevoerd in het kader van de wettelijke onderzoekstaken (WOT Natuur en Milieu: thema 004, WOT Informatievoorziening Natuur).

Omdat zowel de gewone als de grijze zeehonden in Nederland niet een aparte populatie vormen maar deel uitmaken van internationale populaties wordt het beheer internationaal gecoördineerd en in de Waddenzeelanden gesynchroniseerd.

In Europa is afgesproken dat voor de gewone zeehond het maximaal getelde aantal dieren in augustus wordt gebruikt om de populatieontwikkelingen in de verschillende jaren met elkaar te vergelijken (Ecological Quality Objectives, OSPAR; en in navolging hiervan in ICES (WGMM)). Met de andere Waddenlanden (Duitsland en Denemarken) zijn strenge afspraken gemaakt om de tellingen in de drie landen te synchroniseren en te standaardiseren. Uit de twee augustustellingen van de drie 
Waddenlanden wordt de meest betrouwbare en volledige telling gebruikt als index (zie Kader) voor de populatiegrootte in de gehele Waddenzee en deze aantallen worden jaarlijks gepubliceerd. Met deze index wordt de populatieontwikkeling in dit gebied van jaar op jaar gevolgd.

\section{Getelde populatiegrootte ten opzichte van de werkelijke populatiegrootte}

Bij tellingen van zeehonden vanuit het vliegtuig worden alleen individuen geteld die op de kant liggen. Hoeveel zeehonden uit de populatie op de kant komen, is afhankelijk van een aantal factoren zoals de getijdecyclus, tijd van de dag, seizoen, weer, verstoring, tijdsduur waarin de zandbanken droogvallen, voedselbeschikbaarheid en periode waarin geboortes, zogen en paartijd vallen. Er blijkt een duidelijke seizoensinvloed te zijn op het aantal dieren dat wordt geteld. Bij gewone zeehonden worden de hoogste aantallen op de zandbanken waargenomen in de maanden juni en augustus. In beide periodes worden verschillende groepen binnen de populatie geteld. Tijdens de geboorte- en zoogperiode zien we vooral zwangere vrouwtjes, moederdieren met hun jongen en onvolwassen dieren. In augustus tijdens de verharingsperiode worden vooral volwassen mannetjes en vrouwtjes gezien.

Uit het feit dat in de verschillende seizoenen andere groepen uit de populatie worden geteld is al af te leiden dat op geen enkel tijdstip in het jaar de gehele populatie op de zandbanken wordt gezien. Daarom is de telling een index voor de werkelijke aantallen in het gebied. De index kan wel gebruikt worden om bijvoorbeeld de groei van de populatie te volgen. Wil je weten hoeveel dieren in het gebied aanwezig zijn, dan moet er gecorrigeerd worden voor de gemiste dieren. Uit onderzoek (o.a. Ries et al., 1998) is berekend dat tijdens de verharingstellingen ongeveer een derde van de populatie niet op de kant is en dus wordt de totale populatie met dat deel onderschat. Tenzij anders aangegeven, worden in dit rapport de ongecorrigeerde aantallen genoemd.

\subsection{Doel van dit rapport}

In dit rapport wordt uitgelegd hoe de zeehondentellingen voor de gewone zeehond en de grijze zeehond in de Waddenzee worden uitgevoerd en worden de resultaten van de tellingen tot en met 2017 gepresenteerd. Daarbij wordt ook gekeken naar de aantalsontwikkelingen van beide soorten in de Internationale Waddenzee. 



\section{Methode}

\section{Uitvoering}

Zeehonden worden geteld wanneer ze bij laagwater op de zandbanken komen. Om de variatie in telresultaten te minimaliseren, wordt geteld tussen circa 1 uur voor en 1 uur na laagwater, en alleen wanneer het laagwatermoment midden overdag valt (tussen 11.00 uur en 15.00 uur). De telling vindt plaats vanuit een vliegtuig. Er wordt gevlogen op ten minste 500 voet (ruim 150 meter) via een vaste route langs de geulranden van de verschillende zeehondenligplaatsen in de Nederlandse Waddenzee. Voor de gewone zeehonden wordt de gehele Nederlandse Waddenzee geteld en voor de grijze zeehonden alleen het westelijke wad tot Engelsmanplaat (ten oosten van Ameland), omdat tot nu toe nog geen ligplaatsen ten oosten hiervan bekend zijn. Indien nieuwe ligplaatsen bekend worden (b.v. via de bemanning van inspectieschepen van het ministerie van LNV in de Waddenzee, de Wadden Unit) wordt de route aangepast.

De vluchten vinden plaats tijdens de geboorteperiode (juni-juli voor de gewone zeehonden en december-januari voor de grijze zeehonden) en de verharingsperiode (augustus voor de gewone en maart-april voor de grijze zeehond). Dit zijn de periodes waarin gemiddeld de meeste dieren op de kant gezien worden. Om een goed beeld te krijgen van het aantal geboren dieren en het moment waarop het aantal waargenomen jongen piekt, wordt er drie keer in de geboorteperiode geteld. Om de piek in aantallen tijdens de verharingsperiode te bepalen, wordt er twee keer in die periode geteld. Volgens de afspraken in OSPAR is in vrijwel geheel Europa voor de gewone zeehondentelling afgesproken dat in principe de tellingen in de verharingsperiode (augustus) worden gebruikt om de populatieontwikkelingen van jaar op jaar te vergelijken. Omdat de gewone zeehonden in de Internationale Waddenzee als één populatie worden beschouwd, worden de teldatums via het Trilateraal overleg tussen de drie Waddenzee landen Denemarken, Duitsland en Nederland afgesproken, zodat deze zo dicht mogelijk bij elkaar liggen. Zo kan de totale populatiegrootte zo nauwkeuring mogelijk worden bepaald.

In de beginjaren van de monitoring, tot ongeveer 1995, toen er nog relatief weinig zeehonden in de Waddenzee leefden, werden de aantallen direct tijdens de vlucht genoteerd (Reijnders et al., 1995). Maar met de groei van de populatie is geleidelijk overgegaan naar digitale fotografie gekoppeld aan GPS-locatie. Van elke groep zeehonden worden tijdens de vlucht opnames gemaakt die later op het instituut worden geanalyseerd en uitgewerkt. Door middel van een speciaal hiervoor geschreven programma worden de gemaakte foto's van de zeehonden bij het inlezen in de database gekoppeld aan de GPS-gegevens. Bij de uitwerking van de tellingen worden grijze en gewone zeehonden apart geteld. Alleen in de geboorteperiode kan er onderscheid worden gemaakt tussen volwassenen en pups. Wanneer het tijdens het vliegen niet lukt om een groep op camera vast te leggen, wordt deze groep direct vanuit het vliegtuig geteld. Dit wordt later in de database aangevuld. De getelde aantallen worden uiteindelijk gebruikt om de eventuele veranderingen in de populatie te onderzoeken en te beschrijven.

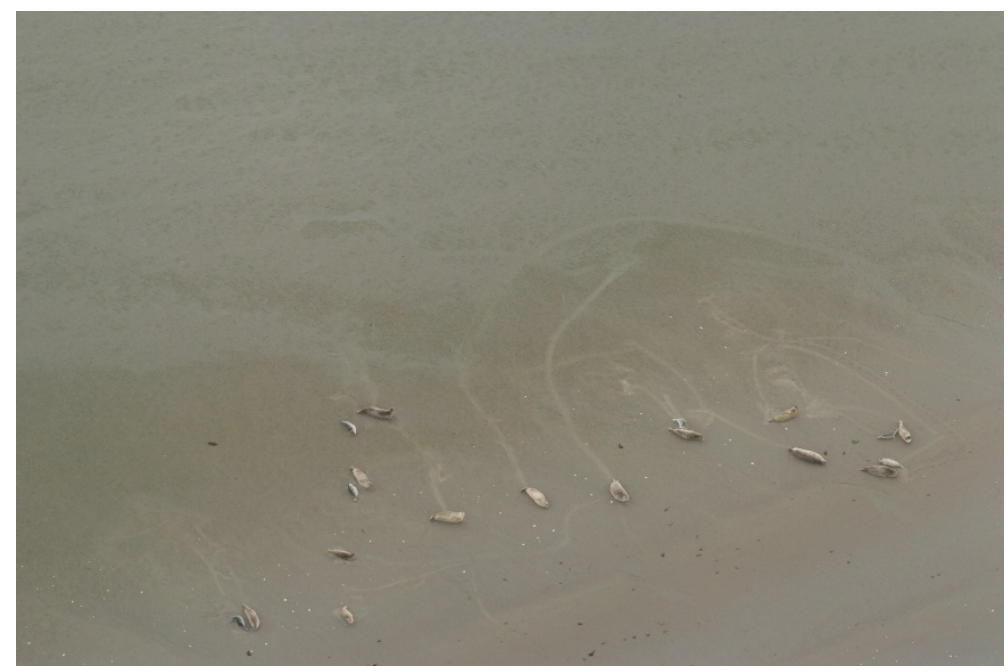




\section{Studiegebied}

Voor de analyse van de data wordt het Nederlands deel van het Waddengebied in twaalf deelgebieden verdeeld op basis van de geulsystemen en wantijen daar tussen (figuur 2). Deze onderverdeling kan gebruikt worden voor analyse van lokale veranderingen. Dit kan met nog meer nauwkeurigheid worden gedaan, op het niveau van individuele ligplaats. Daartoe worden in de database de getelde zeehonden automatisch op basis van de GPS-gegevens gekoppeld aan de dichtstbijzijnde ligplaats. De automatische bepaling van de ligplaatsen resulteert, door de afstand tussen het vliegtuig en de zeehonden zelf, in een globale ligging, die in een enkel geval nog handmatig moet worden aangepast. Voor bepaling van een nog nauwkeuriger ligplaats, de exacte ligplaats, zou achteraf een tijdrovende handmatige controle noodzakelijk zijn. Door de dynamiek van het waddensysteem, dat wil zeggen de zeer veranderlijke hoogte en ligging van zandplaten, is het exact koppelen van de locatie van zeehonden op de platen met bestaande kaarten erg moeilijk.

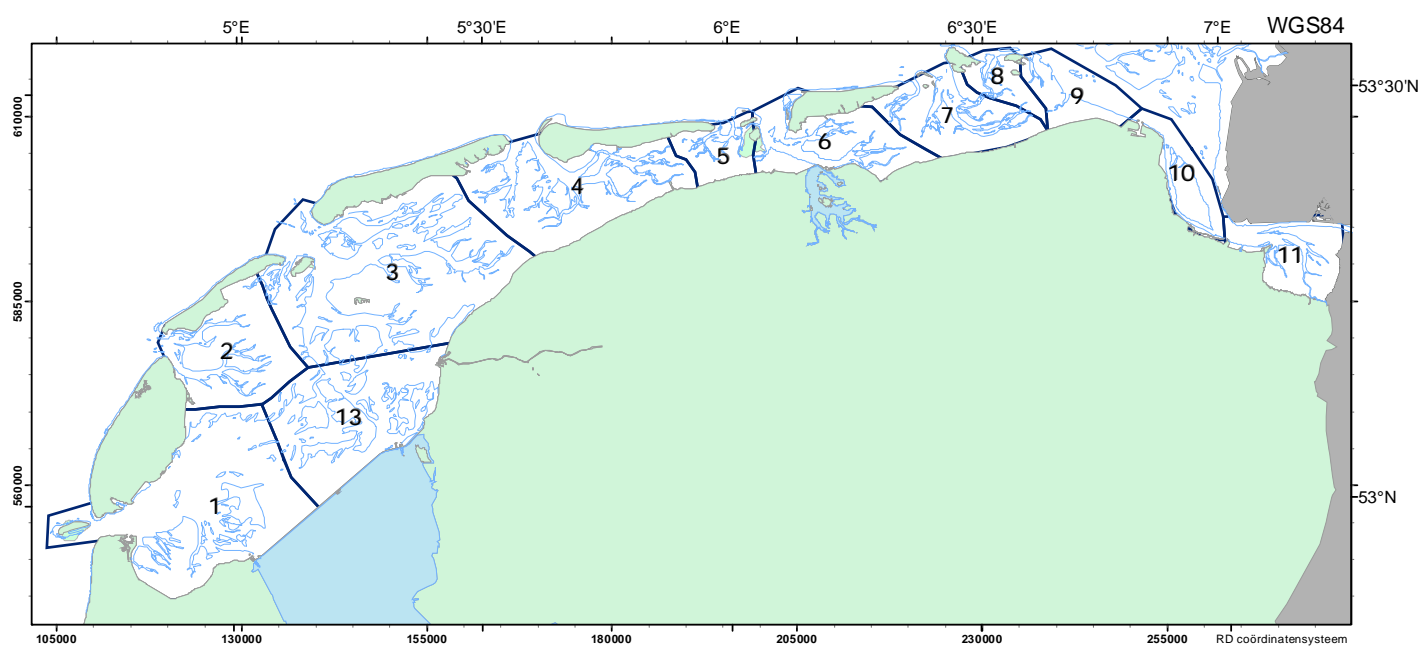

Figuur 2. Indeling van de Nederlandse Waddenzee in zeehondentelgebieden. 


\section{Resultaten}

\subsection{Monitoring in de Internationale Waddenzee}

\subsubsection{Gewone zeehond}

De groei van de aantallen getelde zeehonden in de Nederlandse Waddenzee sinds het laatste PDVvirus is ook zichtbaar in de andere Waddenzeelanden (figuur 3). Gemiddeld zijn in de laatste vijf jaar ruim 25.000 dieren geteld in de internationale Waddenzee. Omgerekend naar de totale populatie (zie kader Hoofdstuk 1) wordt deze geschat op ongeveer 38.000 dieren in 2017 (Galatius et al., 2015). De omvang van de populatie wordt door de Trilateral Seal Expert Group (TSEG) bepaald op basis van de som van de tellingen van de verschillende landen. Zowel de timing als de kwaliteit van de tellingen speelt een rol bij de keuze van de telling. Dit heeft tot gevolg dat niet altijd de beste telling van een land meegenomen wordt, maar de best passende. Zo is in 2017 vanwege de timing van de teldatums voor het Nederlandse deel niet de beste telling (met de hoogste aantallen) gebruikt.

Uit de Waddenzee-breed getelde aantallen blijkt dat de aantallen de laatste jaren min of meer gelijk blijven. Omdat de dieren die in het water zijn niet worden meegeteld, moet bij de interpretatie van de getelde aantallen altijd over een langere periode vergeleken worden. Immers, de aantallen in het water en op de kant, kunnen variëren ten opzichte van het totaal aantal dieren van een populatie. De variatie in aantallen op de kant kan het gevolg zijn van gedragsveranderingen, bijvoorbeeld omdat dieren door omstandigheden tijdens de verharing minder lang op de kant liggen. Ook is het mogelijk dat het seizoen verschuift en dat bij de gestandaardiseerde tellingen de piek gemist wordt. Hiertoe werd in het verleden overeengekomen dat extra tellingen zouden worden uitgevoerd om verschuivingen te meten. Echter, gebrek aan middelen heeft dit de laatste jaren belet.

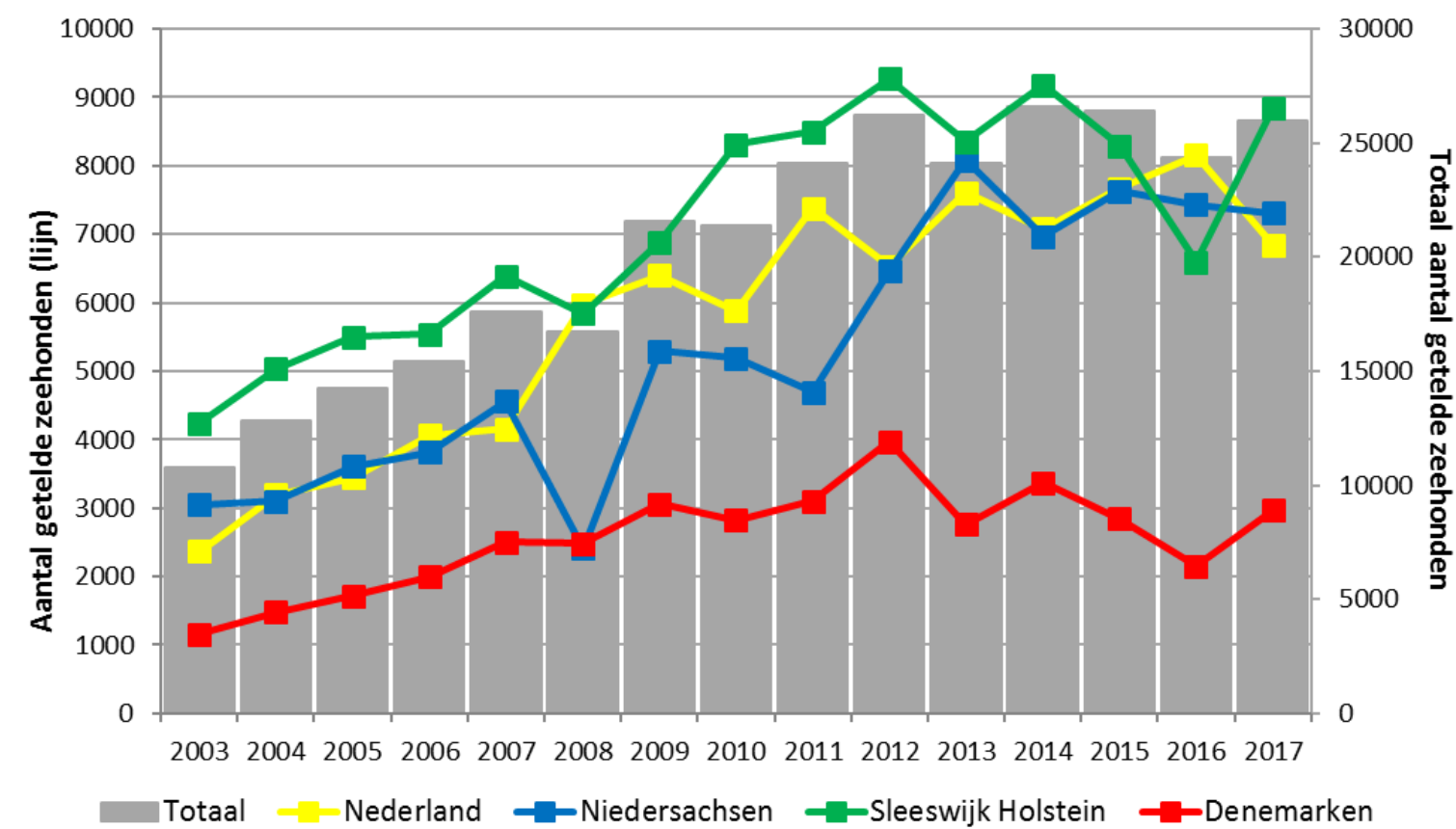

Figuur 3. Aantalsverloop van de gewone zeehond sinds de laatste PDV-epidemie in 2002 in de totale internationale Waddenzee (balken, linker $Y$-as) en in de verschillende afzonderlijke landen (lijnen, rechter $Y$-as) op basis van de gegevens van de TSEG (Galatius et al., 2017). 
In de reproductieperiode (juni/juli voor de gewone zeehond) wordt in de gehele Waddenzee het aantal pups geteld. Internationaal lijken de aantallen getelde pups de laatste jaren min of meer gelijk te blijven (figuur 4). Deze trend is in alle landen/deelstaten waar te nemen. Het lage aantal pups in Sleeswijk-Holstein in 2016 wordt mogelijk veroorzaakt door de griepepidemie uit 2014/2015 die vooral in de oostelijke Waddenzee effect heeft gehad (Galatius et al., 2016). In 2017 lijkt het aantal pups weer te groeien (Galatius et al., 2017).

De onderlinge verschillen tussen de landen zijn wel groot. In Sleeswijk-Holstein worden de meeste pups geboren. Uit onderzoek naar historische tellingen en beschermende maatregelen (zoals het stoppen met de jacht) is gebleken dat beschermende maatregelen lang doorwerken in de populatie (Brasseur, 2017). Zeehondenmoeders keren voor het jongen vaak terug naar de plek waar ze zelf geboren zijn (Härkönen \& Harding 2001; Pomeroy 2005), en bij langlevende soorten als de zeehond heeft dat een effect. In Sleeswijk-Holstein werd de jacht op moeders met pups het eerst verboden en in die regio worden de meeste pups geboren (Brasseur et al., 2017b).

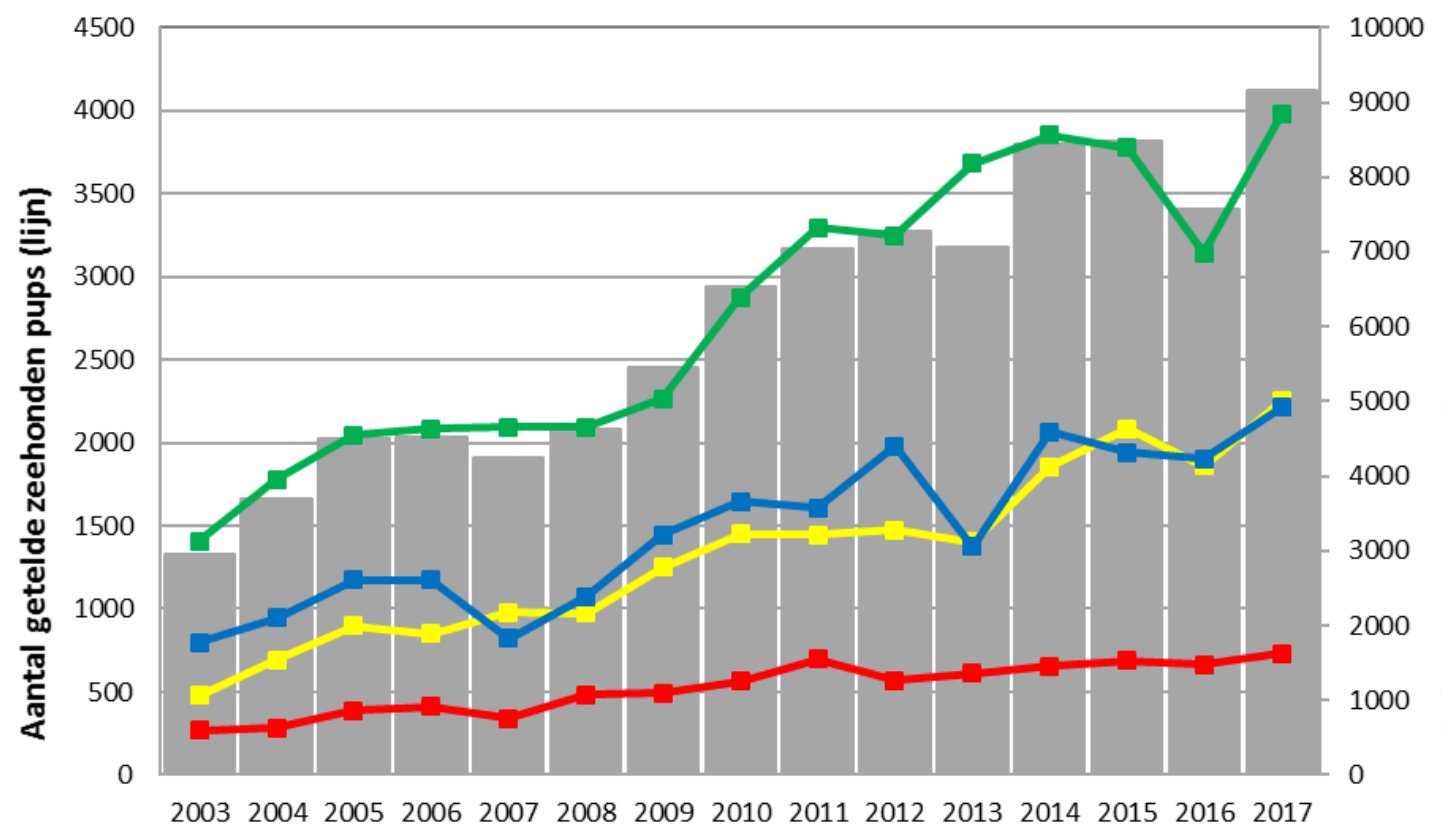

Totaal - Nederland $\rightarrow$ Niedersachsen $\rightarrow$ Sleeswijk-Holstein $\rightarrow$ Denemarken

Figuur 4. Aantal getelde pups van de gewone zeehond sinds de laatste PDV-epidemie in 2002 in de totale internationale Waddenzee en in de verschillende landen op basis van de gegevens van de TSEG.

\subsubsection{Grijze zeehond}

Sinds 40 jaar zijn de grijze zeehonden weer terug in de Duitse Waddenzee (op Amrum werden de eerste waargenomen) en sinds 30 jaar in de Nederlandse Waddenzee, althans toen werd de eerste pup waargenomen. In Nederland werden de eerste dieren waargenomen in gebied 03 tussen Terschelling en Vlieland. Inmiddels zijn de aantallen toegenomen en sinds 2007 zijn de grijze zeehonden opgenomen in het reguliere internationale monitoringsprogramma (Brasseur et al., 2013). Grijze zeehonden verharen in het vroege voorjaar, maart/april, en dan vinden ook de jaarlijkse tellingen voor de populatie-ontwikkelingen plaats. Naast in Nederland en in de beide Duitse deelstaten worden de grijze zeehonden sinds kort ook in Denemarken geteld, maar daar zijn de aantallen zijn nog laag.

De meeste grijze zeehonden (meer dan 75\% van de aantallen in de gehele Waddenzee) komen voor in het Nederlandse deel van de Waddenzee (figuur 5). Ook op Helgoland is al langere tijd een relatief grote groep aanwezig. Dit gebied is om die reden apart opgenomen in figuur 5 . Uit de jaarlijkse tellingen blijkt dat de grijze zeehond zich langzaam uitbreidt naar het oosten. Grijze zeehonden uit de internationale Waddenzee en van de oostkust van het Verenigd Koninkrijk behoren tot dezelfde 
populatie die zich uitstrekt over de zuidelijke Noordzee (Brasseur et al., 2015). Deze waarneming wordt ondersteund door onderzoek aan grijze zeehonden die uitgerust zijn met zenders. Individuen zwemmen regelmatig op en neer en verharen bijvoorbeeld in Nederland en krijgen jongen in het Verenigd Koninkrijk (Brasseur et al., 2017b) of vice versa.

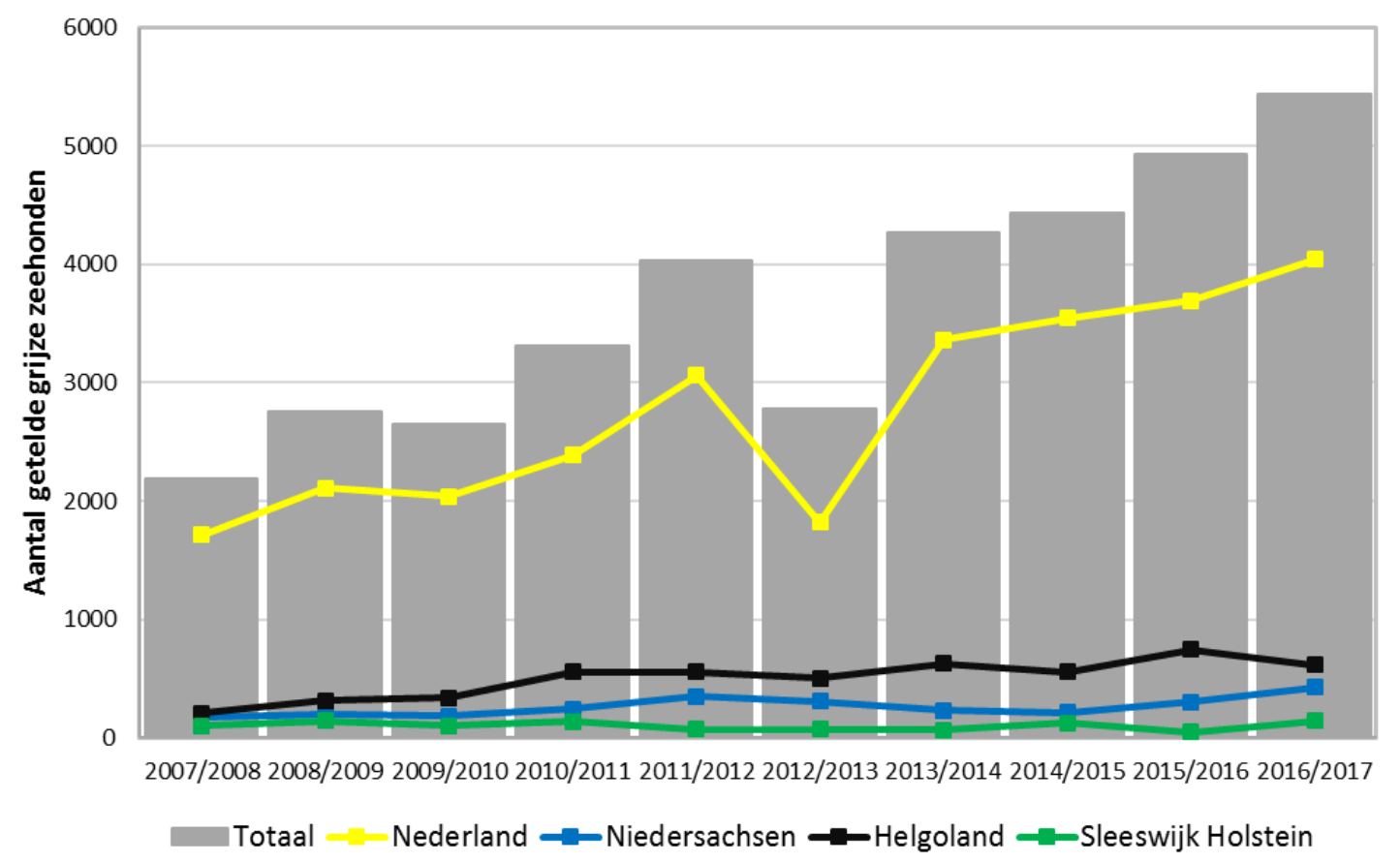

Figuur 5. Aantal getelde grijze zeehonden in de verschillende landen (lijnen) en het totaal aantal geteld in de Internationale Waddenzee (balken).

In 1985 is de eerste pup van de grijze zeehond waargenomen op de zandbanken bij Terschelling (Brasseur et al., 2013). Figuur 6 laat het verloop van de getelde aantallen pups in de verschillende landen zien sinds 2007. De meeste pups worden in de Nederlandse Waddenzee geteld, Helgoland en Niedersachsen volgen daarna. In alle landen en regio's nemen de aantallen pups nog steeds toe.

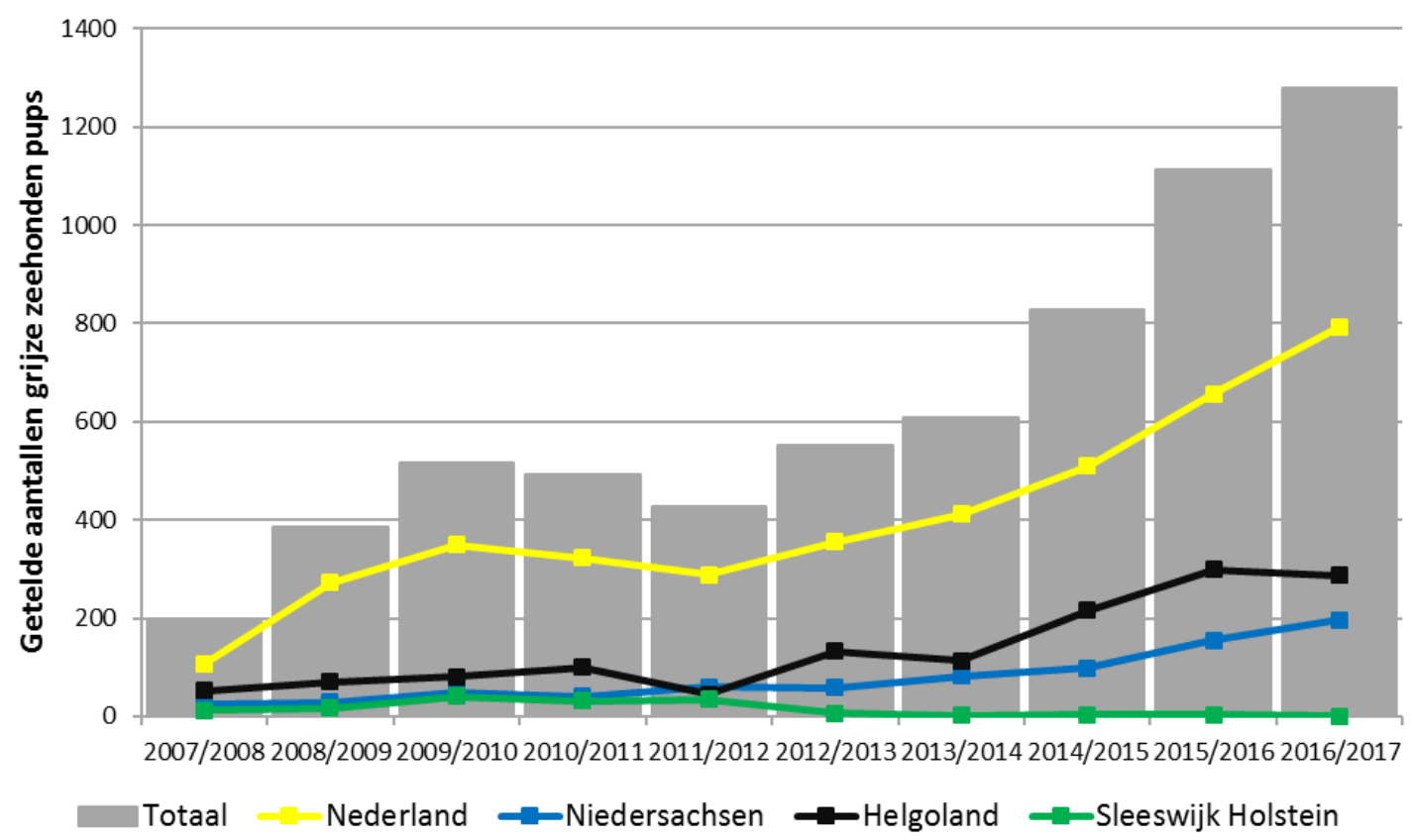

Figuur 6. Het aantal getelde pups van de grijze zeehond in de verschillende landen (lijnen) en het totaal van de internationale Waddenzee (balken). 
De grijze zeehond krijgt haar pups, in tegenstelling tot de gewone zeehond, vooral op de wat hogere platen die gedurende het gehele broedseizoen droog blijven. Op plekken met beginnende duinvorming en vegetatie, zoals de Richel, Engelse Hoek en Griend tussen Vlieland en Terschelling en de Kachelotplate tussen Borkum en Juist in de Duitse Waddenzee, worden de meeste pups geteld. Pups kruipen met hun moeder in de vegetatie en blijven daar een aantal weken: eerst gemiddeld 19 dagen waarbij ze door de moeder gezoogd worden, daarna blijven ze tot een maand alleen achter terwijl hun moeder al naar zee is teruggekeerd.

Het aantal getelde pups in de Nederlandse Waddenzee blijft relatief laag ten opzichte van het aantal getelde grijze zeehonden in de verharingsperiode (figuur 7). De pup/adult ratio van de grijze zeehond is lager dan van de gewone zeehonden (tabel 1); de groei in aantallen daarentegen is hoger. Een groei van $10 \%$ past bij een evenwichtige populatieopbouw (Härkönen et al., 2002). Een deel van de toename van de grijze zeehond in de Nederlandse Waddenzee wordt verklaard door immigratie en niet door de reproductie (Brasseur et al., 2015). De dieren uit de Waddenzee zijn namelijk onderdeel van de populatie in de zuidelijke Noordzee. Naast een permanente immigratie blijkt dat een deel van de dieren wel van het Waddengebied gebruik maakt, maar voor de voortplanting terugkeert naar het Verenigd Koninkrijk.

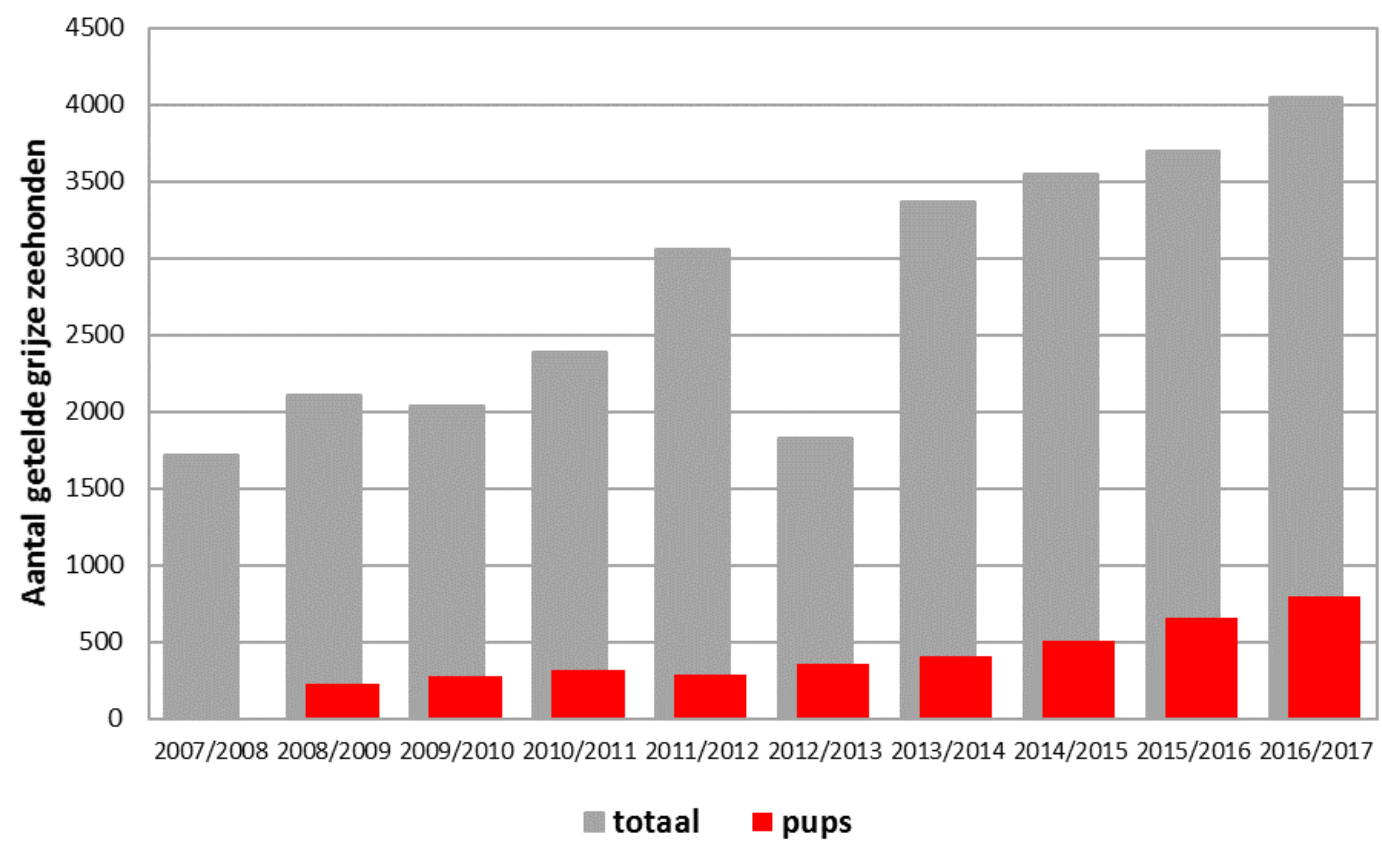

Figuur 7. Het totaal aantal getelde grijze zeehonden (tijdens de verharing) en pups (tijdens de reproductie) sinds 2007 in de Nederlandse Waddenzee.

Tabel 1. De gemiddelde pup/adult verhouding en het gemiddelde groeipercentage per jaar over de laatste 10 jaar van beide zeehondensoorten. Tussen haakjes de range, waarbij van alle series de hoogste en de laagste waarde buiten beschouwing zijn gelaten. De invloed van eventuele telfouten wordt hierdoor geminimaliseerd.

\begin{tabular}{lcc} 
& Pup/adult & Gemiddelde jaarlijkse \\
\hline Gewone zeehond & $0.23(0.18-0.27)$ & $10.34 \%(-16 \%-43 \%)$ \\
\hline Grijze zeehond & $0.12(0.09-0.14)$ & $12.41 \%(-3 \%-28 \%)$ \\
\hline
\end{tabular}




\subsection{Gebiedsgebruik}

\subsubsection{Deelgebieden}

Door de ligplaatsbepaling worden de getelde aantallen toegekend aan een deelgebied (zie figuur 1). Omdat de deelgebieden verschillen in grootte en aanwezigheid van geschikte ligplaatsen, en daarmee ook van de getelde aantallen, is het lastig deze gebieden onderling te vergelijken. We kunnen wel iets zeggen over de trends binnen elk gebied.

\subsubsection{Gewone zeehond}

Om iets te kunnen zeggen over het gebiedsgebruik van de zeehonden zijn de maximaal getelde aantallen zeehonden een goede maat. Om de trend van de getelde aantallen zeehonden binnen een gebied te laten zien, zijn in figuur 8 (rode lijn) de maximaal getelde aantallen per jaar per deelgebied uitgezet.

De meeste deelgebieden vertonen sinds de laatste PDV-epidemie in 2002 een groei in aantallen (figuur 8). Vanaf omstreeks 2009 zijn er deelgebieden (gebieden 02, 03, 04 en 05) waar de getelde aantallen niet meer lijken toe te nemen, maar, met variatie, min of meer gelijk blijven. In andere gebieden (gebieden 01, 07, 08 en 09) daarentegen nemen de aantallen ook de laatste jaren nog steeds toe, waarbij opvalt dat de aantallen in gebied 01 na 2009 sterker toenemen dan in de periode ervoor.

Figuur 8 geeft ook een overzicht van de maximaal getelde aantallen pups in de verschillende deelgebieden (zwarte lijn). In de oostelijke Waddenzee worden de meeste pups geteld (gebieden 07, 08 en 09), maar ook in de westelijke Waddenzee (gebied 03) worden pups gezien. Omdat de deelgebieden qua grootte onderling verschillen kunnen ook bij de pup-tellingen de gebieden niet goed vergeleken worden. Wel is duidelijk dat verschillen tussen de gebieden veel groter zijn dan bij de tellingen tijdens de verharing. En in de gebieden waar de meeste pups worden geteld nemen de aantallen pups nog steeds toe.

Om toch iets te kunnen zeggen over het belang van deelgebieden en de verschillen tussen reproductie en verharing is de pup/adult ratio bepaald. Uit de relatie tussen de maximaal getelde aantallen pups tijdens de reproductie en het maximaal getelde aantal zeehonden tijdens de verharing blijkt dat die relatie niet overal hetzelfde is. Opvallend is dat de gebieden waar in de zomer de meeste pups worden geteld, niet dezelfde zijn als de gebieden waar tijdens de verharing de meeste zeehonden op de kant worden gezien (zie figuur 9). Gebied 11 bijvoorbeeld, de Dollard, heeft de hoogste pup/adult ratio, maar heeft een laag aandeel in het tijdens de verharing getelde totaal aantal in de Nederlandse Waddenzee. De gebieden in de oostelijke Waddenzee (vierkante blokjes) hebben een hogere pup/adult ratio dan de gebieden in het westelijk deel (rondjes). De stippellijn is de gemiddelde relatie pup/adult ratio over de betreffende jaren. De gebieden links van de lijn hebben een hogere ratio en de gebieden rechts een lagere.

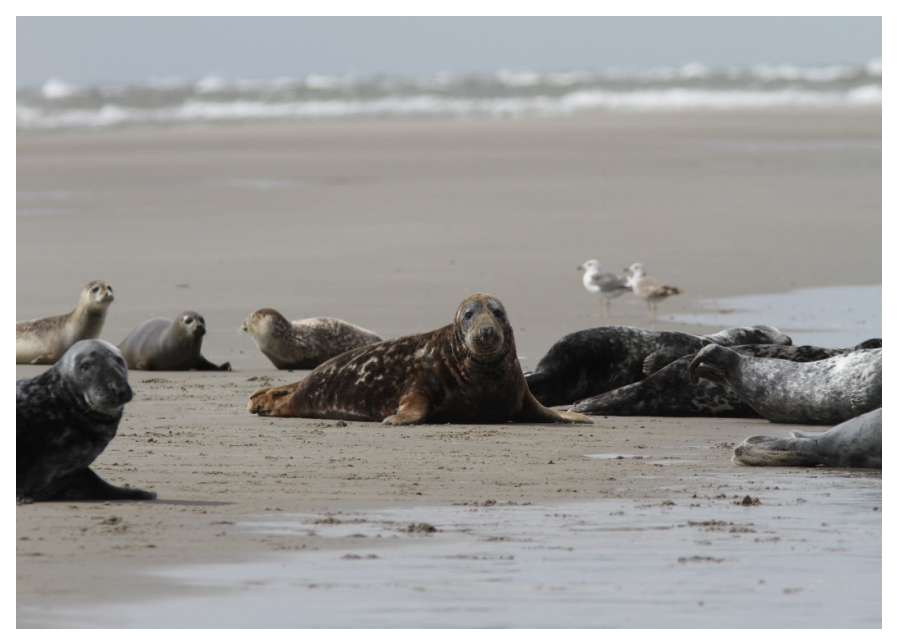

Grijze zeehond (voorgrond) en gewone zeehond (Foto: Hans Verdaat) 

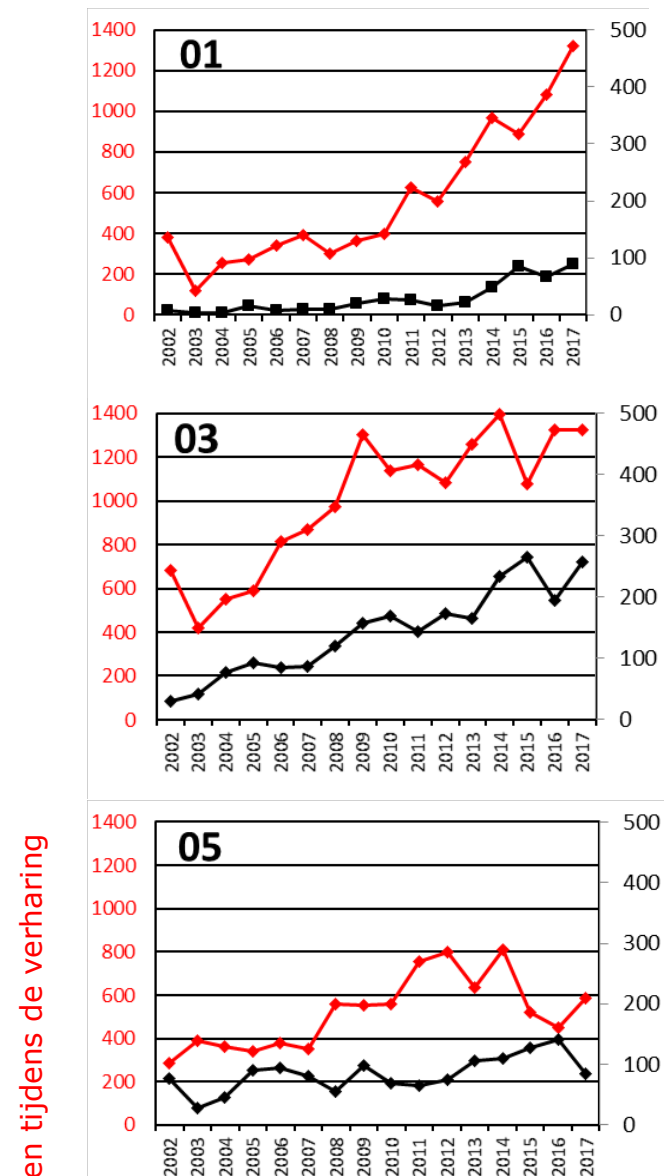

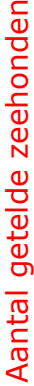
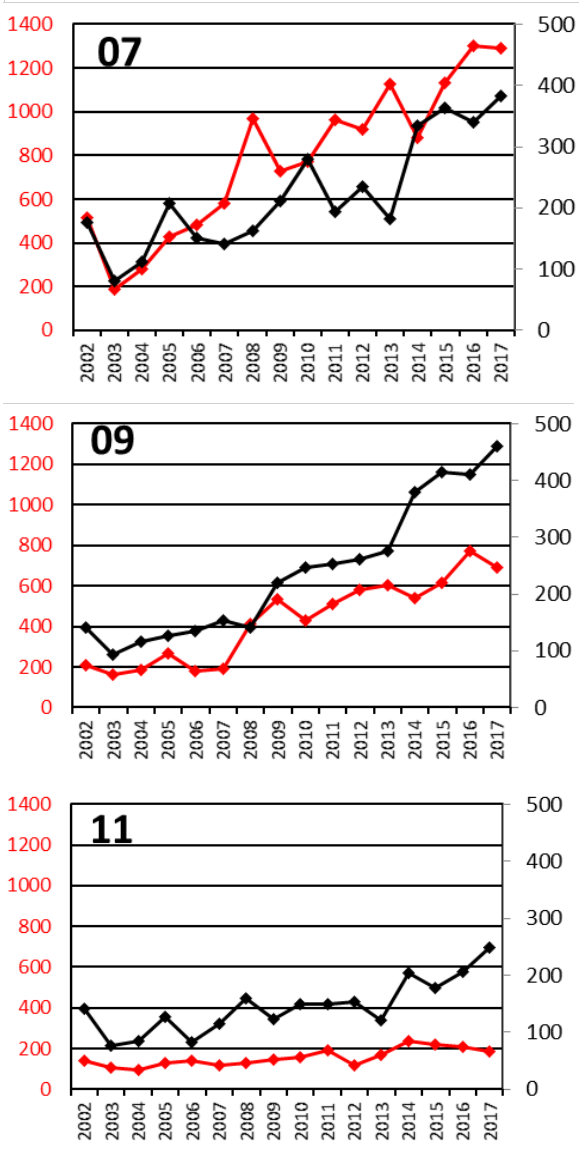

- Aantal pups
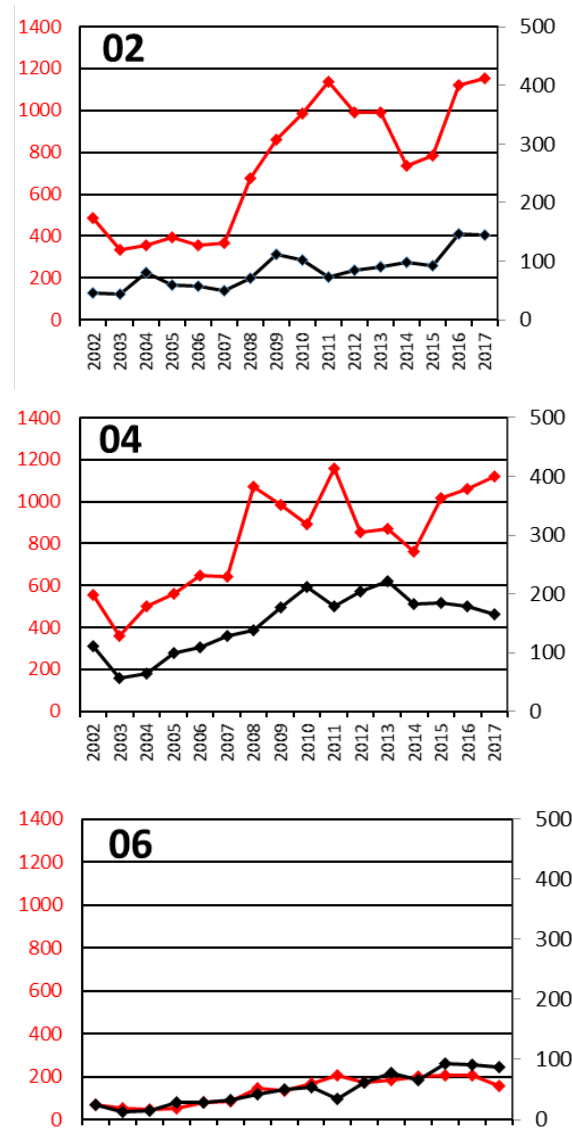

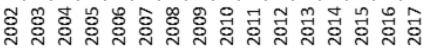

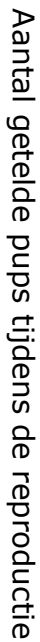

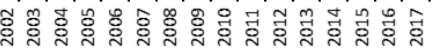
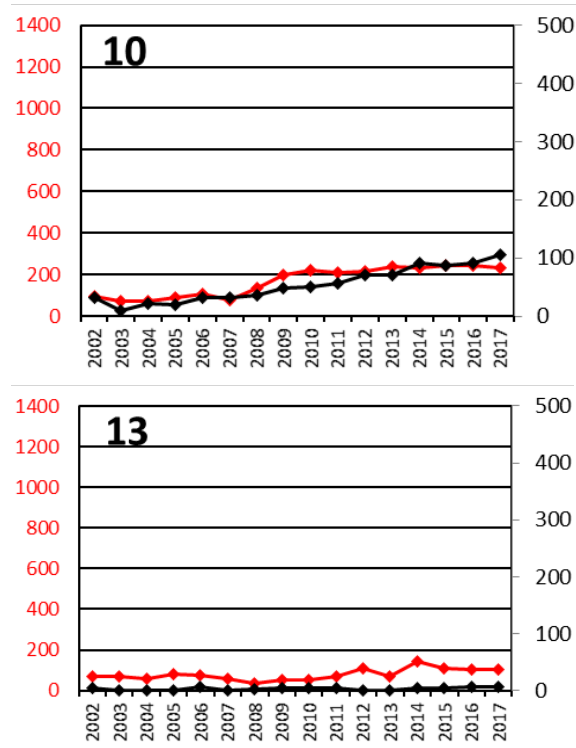

Figuur 8. Verloop van de maximaal getelde aantallen gewone zeehonden tijdens de verharing (rood; linker as) en de maximaal getelde aantallen pups (zwart; rechter as) in de verschillende deelgebieden (zie ook figuur 1). 


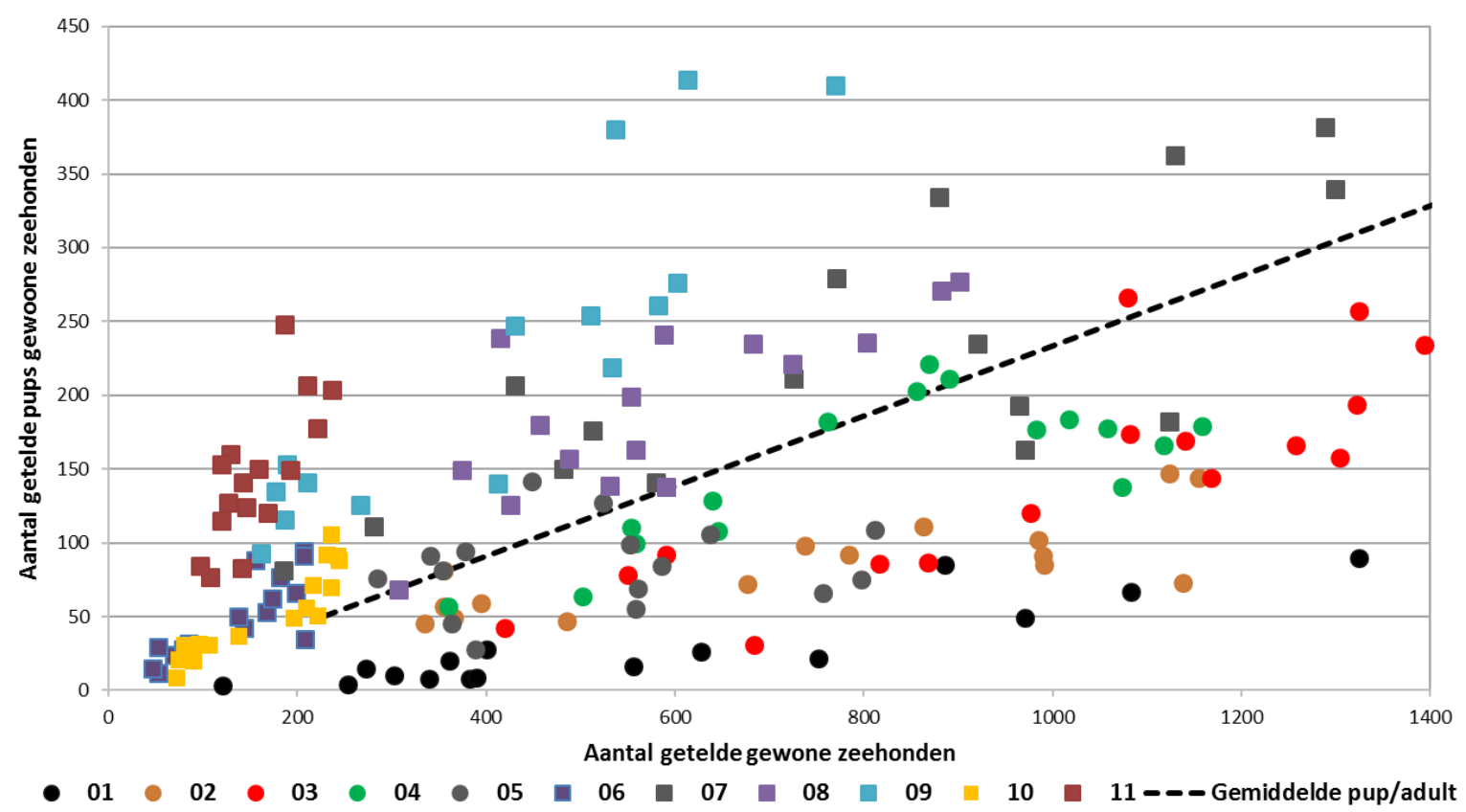

Figuur 9. Maximaal aantal getelde pups en maximaal aantal getelde adulte gewone zeehonden per deelgebied per jaar over de periode 2002-2017. Er is onderscheid gemaakt tussen de oostelijke ( $\square$ ) en de westelijke gebieden (•). De stippellijn geeft de gemiddelde verhouding aan tussen totaal aantal pups en adulte zeehonden.

\subsubsection{Grijze zeehond}

Grijze zeehonden komen in Nederland voornamelijk in het westelijk deel van de Waddenzee voor. Het aantal getelde grijze zeehonden was ruim 4000 in 2017 . Uit figuur 10 blijkt dat het merendeel daarvan in gebied 03 voorkomt (gemiddeld meer dan $60 \%$ in de laatste drie jaar). En hoewel de totaal getelde aantallen grijze zeehonden in de Nederlandse Waddenzee blijven toenemen (zie figuur 5), is dat niet het geval in gebied 03. In gebied 01, waar de grijze zeehonden vooral op de Noorderhaaks liggen, nemen de getelde aantallen de laatste jaren wel toe. In de andere gebieden blijven de getelde aantallen nog laag, in het oostelijk deel van de Nederlandse Waddenzee worden weinig of geen grijze zeehonden geteld.

Voor de getelde aantallen pups neemt gebied 03 meer dan $95 \%$ van de in Nederland geboren pups voor zijn rekening. En hoewel er ook in gebied 01 en 02 pups worden geboren, zijn dit relatief lage aantallen. De aantallen in gebied 03 groeien nog steeds (figuur 11).

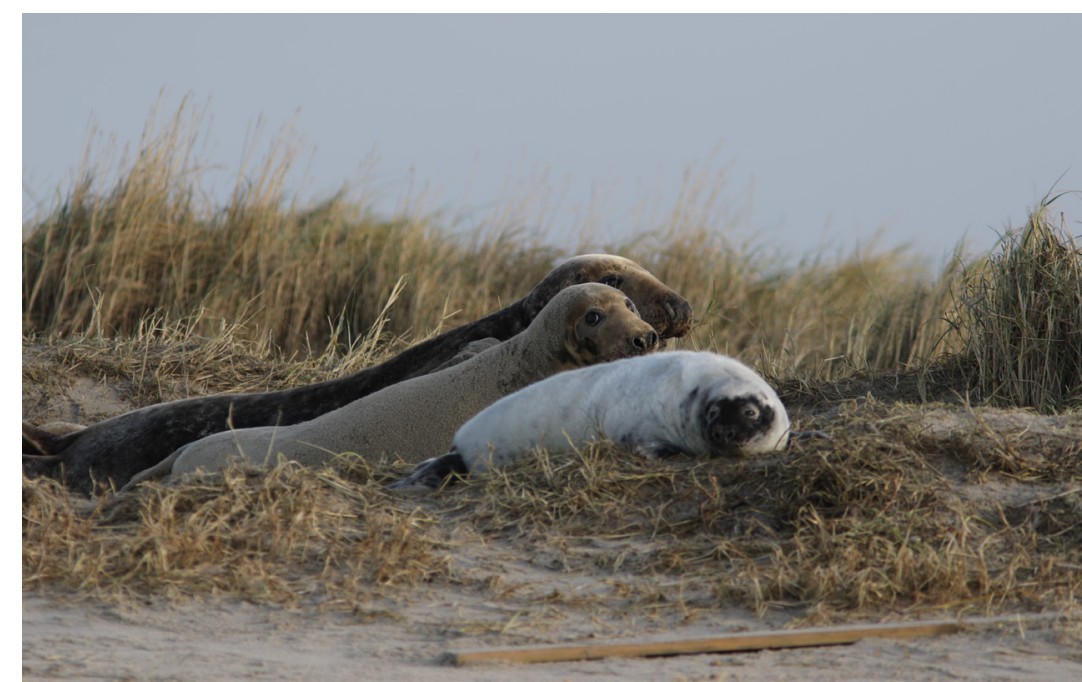

Grijze zeehonden met pup op zandplaat De Richel in de Waddenzee (Foto: Sophie Brasseur) 

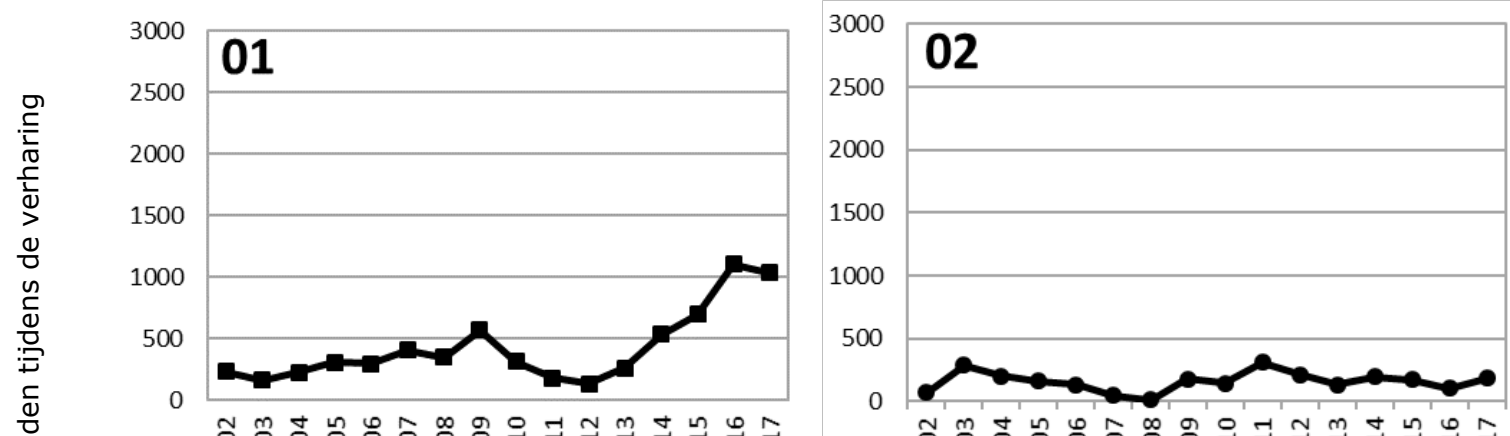

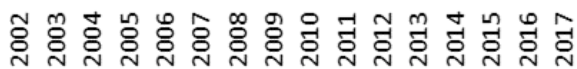
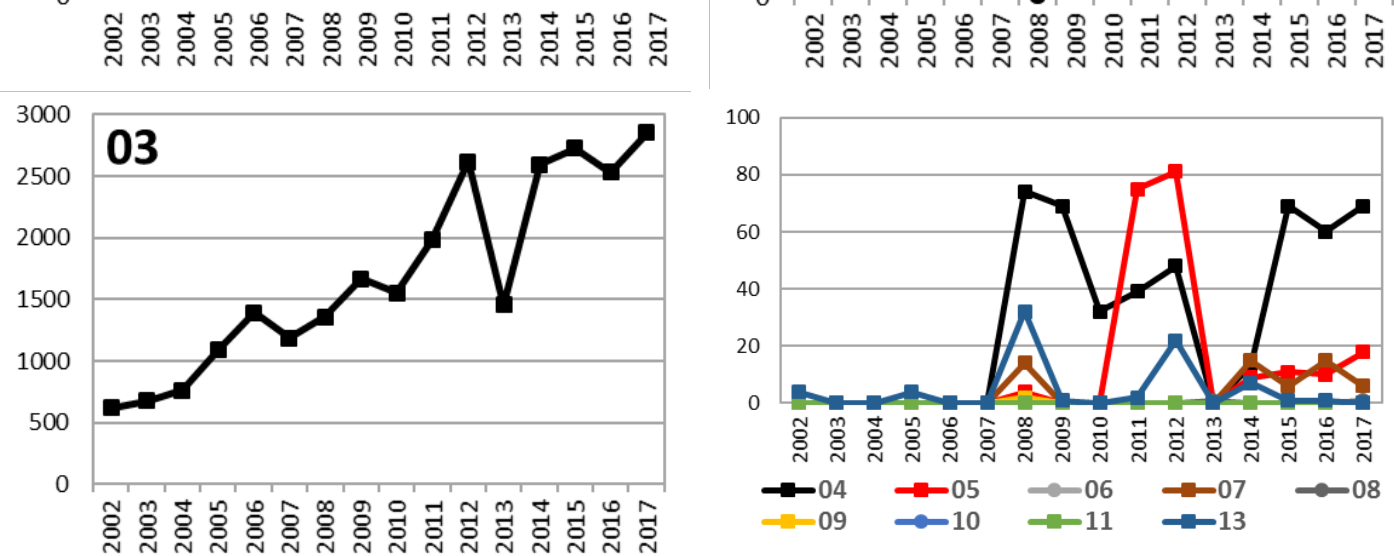

Figuur 10. Maximaal aantal getelde grijze zeehonden in de belangrijkste gebieden (01, 02 en 03$)$ en de resterende deelgebieden (04 t/m 13, samen in één grafiek met afwijkend $Y$-as).

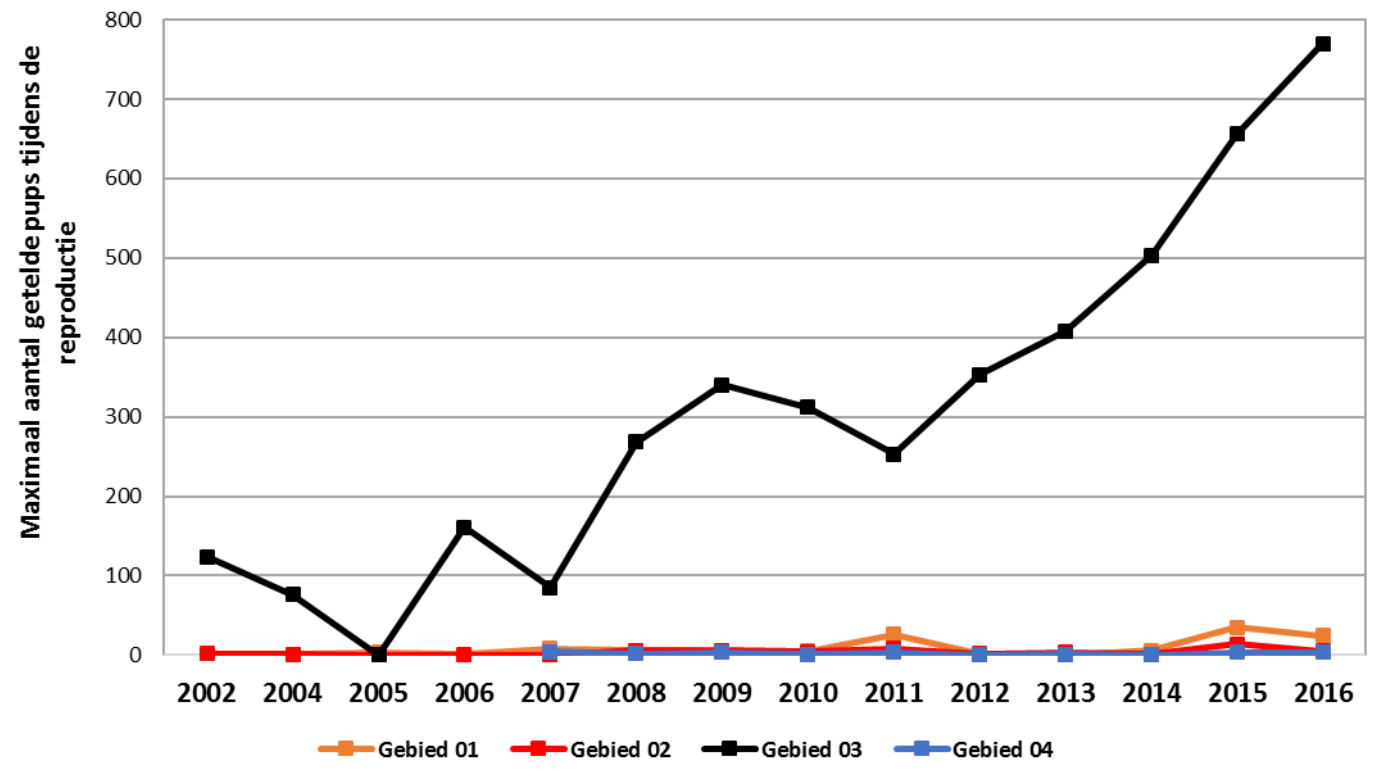

Figuur 11. Maximaal aantal getelde grijze zeehondenpups tijdens de reproductie in december in deelgebieden 01, 02, 03 en 04. In de andere deelgebieden zijn nog nauwelijks pups geteld (max 2 in 05, en 1 in 06 en 07). 


\section{$4 \quad$ Discussie}

\subsubsection{Tellingen}

Het aantal zeehonden dat tijdens een telling op de zandplaten wordt geteld, is een onderschatting van het totaal aantal aanwezige zeehonden in het gebied. Immers, de zeehonden die in het water zijn worden niet gezien en dus niet geteld. Door altijd in dezelfde periode te tellen, tijdens de verharing wanneer een 'vast' percentage zeehonden op de op de kant liggen, wordt het mogelijk de groei van de populatie te volgen en een zo goed mogelijke indicatie voor de aantallen te geven. De aantallen dienen dus als index van de populatie en niet als een populatieschatting. Eerder onderzoek bij de gewone zeehond heeft uitgewezen dat in de zomer gemiddeld twee derde (68\%) van de zeehonden op de ligplaatsen aanwezig is (Ries et al., 1998). Voor grijze zeehonden is het moeilijker te schatten omdat er continu uitwisseling is met andere Noordzeelanden. Het aantal pups is ook een indicatie voor de ontwikkeling van de populatie. Naar schatting wordt bij de piek in aantallen pups van gewone zeehonden $70 \%$ van het totale aantal geboren pups geteld (Brasseur et al., 2018).

Het blijft moeilijk exact aan te geven hoeveel dieren de totale populatie telt. Zo kunnen tijdens zo'n telling om diverse redenen de aantallen variëren. Een verstoring kort voor de telling kan er voor zorgen dat er meer dieren in het water zijn dan normaal. Ook het weer kan van invloed zijn. Als het weer de dagen voor de telling slecht en stormachtig is geweest, liggen er op de eerste rustige (tel)dag relatief meer dieren op de kant (Brasseur et al., 1996). Bij heel warm weer zijn er juist weer meer dieren in het water om af te koelen.

Andere factoren, zoals een verschuiving in de piek van de pup-tijd (Reijnders et al., 2010) of een veranderende voedselbeschikbaarheid (Aarts et al., in prep.), kunnen ook een rol spelen. Bij het bepalen van het beste moment om te tellen, wordt zo veel mogelijk met al deze factoren rekening gehouden. Toch moet bij het gebruik van de tellingen om de ontwikkeling en de trends van de populatie te bepalen, de tellingen bekeken worden over een langere periode; plotse veranderingen van jaar op jaar, kunnen immers het gevolg zijn van een van de bovengenoemde factoren. Recent is er voor het Nederlandse deel van de Waddenzee voor zowel de gewone als de grijze zeehonden een analyse uitgevoerd van de langetermijntrends (Brasseur et al., 2015; Brasseur et al., 2018). Voor beide soorten wordt zichtbaar hoe de aantallen herstellen en welke factoren hierbij een rol hebben gespeeld. Met de tellingen in de komende jaren zal mogelijk duidelijker worden hoe de populaties 'volwassen' worden waarbij deze groeien naar een mogelijk evenwicht, aangezien de populatie niet oneindig kan blijven groeien.

\subsubsection{Ligplaatsen}

Geulen en platen in een getijdengebied zijn voortdurend aan verandering onderhevig. Niet alleen de hoogte van de plaat of de toegankelijkheid naar open water kan bepalend zijn voor de keuze van een ligplaats, maar ook het voorkomen van voedsel in de buurt kan van invloed zijn. Daarnaast kunnen menselijke activiteiten zoals scheepvaart, toerisme en visserij van invloed zijn op de aanwezige aantallen zeehonden op de ligplaatsen. Een geomorfologisch perfecte ligplaats kan door verstoring toch minder geliefd worden en dat heeft invloed op het aantal dieren wat er ligt. Door het sluiten van een aantal gebieden in de Waddenzee wordt een deel van de ligplaatsen beschermd, waarbij het gaat om de belangrijkste plekken voor het jongen en voor de verharing. Ondanks de groei van de populatie is de totale oppervlakte aan beschermde gebieden sinds omstreeks 2009 vrijwel onveranderd gebleven. Daardoor komen steeds meer dieren op platen in de open gebieden te liggen. 


\subsubsection{Draagkracht}

Werd een aantal jaren geleden nog geconstateerd dat de getelde aantallen van de gewone zeehond sterk toenamen (Brasseur et al., 2013), uit de in dit rapport gepresenteerde resultaten lijkt de groei min of meer tot stilstand te komen. De Trilateral Seal Expert Group (TSEG) meldt in haar jaarlijkse rapportage (Galatius et al., 2015; 2016; 2017) dat op basis van de tellingen in de verharingsperiode, er aanwijzingen zijn dat de draagkracht van de Waddenzee voor de gewone zeehond wordt bereikt. Het is echter onduidelijk waarom het aantal jongen de laatste jaren wel blijft toenemen (Galatius et al., 2017).

Bepalen of de draagkracht van een gebied voor zeehonden bereikt is, is complex. Er zijn veel factoren die van invloed zijn op de aanwezige en getelde aantallen dieren. Reproductie en sterfte, emigratie en immigratie zijn de sturende mechanismen die de omvang van een populatie bepalen. Voedselbeschikbaarheid, geschikte ligplaatsen, verstoring en ziektes werken via deze sturingsmechanismen op de aantallen dieren in de populatie. Bijvoorbeeld voedseltekort of te weinig geschikte ligplaatsen kan emigratie stimuleren, ruim voldoende voedsel juist het tegenovergestelde. Recent onderzoek (Aarts et al., in prep.; Daan et al., 2005) laat bijvoorbeeld zien dat de visbestanden in de Waddenzee en kustgebieden sterk zijn afgenomen en hierdoor onvoldoende zijn voor de zeehonden. Zeehonden moeten wellicht nu verder van de kust foerageren. Ook dit kan in de toekomst mede bepalend zijn voor de uiteindelijke populatiegrootte.

Om zicht te krijgen op het belang van voedselbeschikbaarheid helpt kennis over waar de zeehonden zich ophouden buiten de reguliere telperiodes. Voor de grijze zeehonden kunnen de tellingen van de gewone zeehond in de zomer gebruikt worden, omdat de gehele Waddenzee wordt geteld en tijdens deze tellingen dus ook alle grijze zeehonden worden geteld. Andersom is dat niet mogelijk, omdat de tellingen van de grijze zeehonden (in het winterhalfjaar) slechts die gebieden van de Waddenzee betreffen waar grijze zeehonden zich ophouden waardoor een deel van de gewone zeehonden niet geteld kunnen worden.

Om vast te stellen of de draagkracht van een gebied bereikt is, is kennis van al deze aspecten en een diepgaande analyse noodzakelijk. Dat valt buiten het bereik van deze rapportage, maar zou in de toekomst uitgevoerd kunnen worden.

De vraag die in de komende jaren beantwoord zal moeten worden is of de verandering in groeisnelheid van de populatie een aanwijzing is dat de draagkracht van het gebied voor de gewone zeehonden benaderd wordt. Verdere vragen zijn welke factoren bepalend zouden kunnen zijn voor de draagkracht en welke processen leiden tot de beperking van de groei van de gewone zeehondenaantallen. $\mathrm{Nu}$ is het beeld nog niet duidelijk: indien de draagkracht van Waddenzee werkelijk bereikt zou zijn, zouden in alle deelgebieden de getelde aantallen moeten stagneren en dat is niet het geval. Er lijken nog voldoende ongebruikte zandbanken in de Waddenzee te zijn.

\subsubsection{Gewone zeehond}

In de Nederlandse Waddenzee zijn voor de monitoring deelgebieden onderscheiden (figuur 1 ). In sommige van deze deelgebieden $(02,03,04,05)$ nemen de getelde aantallen de laatste jaren niet meer of amper toe, terwijl de aantallen in andere gebieden $(01,07,08,09)$ juist wel toenemen. Weliswaar kunnen ligplaatsen voor wat betreft de fysische geomorfologie in een dynamisch getijdegebied in de tijd veranderen en daardoor minder of juist meer aantrekkelijk worden, de verwachting is niet dat deze veranderingen zo snel gaan dat grote verschillen in getelde aantallen binnen een deelgebied hierdoor verklaard kunnen worden. De vraag wat deze verschillen tussen de deelgebieden zou kunnen veroorzaken is daarom niet eenvoudig te beantwoorden.

Een van de mogelijke oorzaken van het lokaal stagneren van de aantallen zou verstoring kunnen zijn. Het zomerhalfjaar, wanneer de gewone zeehond jongen krijgt en verhaart, is ook het seizoen waarin het druk is op het water. Het aantal rondvaartboten dat met toeristen zeehonden gaat kijken neemt de laatste jaren toe. En daarmee de druk op ligplaatsen buiten de gesloten gebieden. Maar ook andere factoren, zoals de aanwezigheid van voldoende voedsel in het omringende water en de invloed van 
visserij of een combinatie ervan kunnen een rol spelen. Het onaantrekkelijker worden van het ene gebied kan de aantrekkelijkheid van een ander gebied verhogen.

Uit de relatie tussen de aantallen getelde pups in de reproductieperiode en de aantallen getelde zeehonden tijdens de verharing, blijkt dat deze in de oostelijke deelgebieden van de Nederlandse Waddenzee hoger is dan in het westelijke deel (figuur 10). Dat betekent dat zwangere vrouwtjes de voorkeur geven aan een ligplaats in de oostelijke Waddenzee om te jongen, terwijl de dieren tijdens de verharing relatief vaker kiezen voor ligplaatsen in het westelijk deel van de Waddenzee.

De factoren die de keuze voor een gebied of ligplaats bepalen lijken tijdens de reproductieperiode anders te zijn dan tijdens de verharingsperiode. Onderzoek heeft in het verleden aangetoond dat zwangere vrouwtjes een voorkeur hebben om terug te gaan naar de plek waar ze zelf geboren zijn om hun jong te krijgen (Härkönen en Harding, 2001; Pomeroy, 2005). Gebieden waar al veel pups worden geboren blijven daardoor in trek, en doordat de zeehond een langlevende soort is, blijven deze voorkeuren lang bestaan. De timing van het invoeren van beschermende maatregelen blijkt voor de zeehonden nog lang zichtbaar te zijn in de populatie (Brasseur, 2017).

Voordat de jacht volledig werd gesloten in de jaren zeventig was in Duitsland, in tegenstelling tot Denemarken en Nederland, de jacht op moeders en jonge zeehonden tijdens de voortplanting verboden. Tot op heden worden juist daar de meeste pups van de gehele internationale Waddenzee geboren (Brasseur et al., 2017a). Vrouwtjes uit Nederland trekken nu nog steeds naar het oosten om te baren. Feit blijft dat er, naast de plaatstrouwheid van zwangere vrouwtjes, nog weinig bekend is over de factoren die de keuze van de zeehond om op een bepaalde ligplaats te verharen of jongen te krijgen bepalen. Kennis daarvan zou het gericht en efficiënter beschermen van voor de zeehonden belangrijke gebieden kunnen verbeteren.

Een gedetailleerde analyse van de aantallen en vooral de precieze plek waar zwangere vrouwtjes liggen zou informatie kunnen geven over de voorkeuren op kleine schaal. Dit kost veel tijd, maar zou een interessante toevoeging aan onze kennis omtrent hun voorkeuren voor ligplaatsen kunnen zijn.

\subsubsection{Grijze zeehond}

De getelde aantallen grijze zeehonden nemen nog steeds toe, zowel internationaal als in de Nederlandse Waddenzee (Brasseur et al., 2017c). Voor deze soort lijkt, in tegenstelling tot de gewone zeehond, de draagkracht van het gebied nog niet bereikt en de aantallen breiden zich uit naar het oosten. Tijdens de verharing worden de meeste dieren in Nederland in deelgebied 03 geteld (figuur 1), dit is ook het gebied waar bij terugkeer van de soort in Nederland in de jaren tachtig de eerste grijze zeehonden zijn waargenomen. Ondanks de toename van de totaal getelde aantallen, lijken de aantallen in deelgebied 03 te stabiliseren en nemen de getelde aantallen in deelgebied 01 de laatste jaren steeds meer toe.

Grijze zeehonden hebben de neiging aan de noordwestkant van de Waddenzee te blijven, hoewel individuen in toenemende mate ook verder de Waddenzee op worden geteld (figuur 10). In deelgebied 03 worden de meeste pups op de Richel geboren terwijl de verharende grijze zeehonden vooral op de Engelse hoek liggen, een plaat aan de noordwestkant van Terschelling. Die voorkeur zou kunnen verklaren waarom het vooral gebied 01 is, en dan met name de Noorderhaaks, waar de aantallen nu het meest toenemen. De vraag waarom de aantallen op de Engelse hoek niet meer toenemen, of waarom de dieren niet meer gebruik maken van ligplaatsen meer naar het oosten is daarmee niet beantwoord. Tijdens de tellingen van de gewone zeehonden in de zomer worden bij de Engelse Hoek regelmatig grote aantallen in het water waargenomen. Verstoring zou daar de oorzaak van kunnen zijn en mogelijk een verklaring voor de stagnatie in aantallen. Inmiddels wordt gesproken over het invoeren van beschermende maatregelen rond de Engelse Hoek, zoals de invoering van een minimale afstand tot de rustende zeehonden.

Tijdens de eerste weken van hun leven blijven de pups van de grijze zeehonden op de kant, waarbij ze door de moeder gezoogd worden. De pups kruipen hoog op de kant en, indien aanwezig, in de vegetatie. Een onbewoonde en deels begroeide zandplaat als de Richel is voor de reproductie van 
groot belang, net als Griend waar nu ook in toenemende mate jonge pups worden geteld.

Bescherming van deze gebieden en het bewaren van de rust daar is van groot belang voor deze soort. Het aantal getelde pups van de grijze zeehond laat een stijgende lijn zien, waarbij de meeste pups in gebied 03 worden geboren. Omdat dit het enige gebied is waar substantieel veel pups worden geteld kan geen vergelijking met andere gebieden gemaakt worden, wel geeft het aan dat juist dit gebied belangrijk is voor de grijze zeehond.

Het aantal getelde pups dat in de Waddenzee wordt geboren, kan niet geheel de toename van het aantal grijze zeehonden in de internationale Waddenzee verklaren. Ook immigratie uit onder andere het Verenigd Koninkrijk draagt daaraan bij (Brasseur et al., 2015). Er vindt regelmatig uitwisseling plaats tussen de Waddenzee en het Verenigd Koninkrijk. Dit betekent dat grijze zeehonden in het zuidelijk deel van de Noordzee tot één populatie gerekend kunnen worden. Bij bescherming van de grijze zeehond zal met dit gegeven rekening moeten worden gehouden, bijvoorbeeld wanneer het gaat over het opheffen van beschermende maatregelen in het ene land, wat ook gevolgen kan hebben voor de aantallen in de omringende landen. 


\section{$5 \quad$ Conclusie}

Uit de resultaten blijkt dat vooral van de getelde aantallen gewone zeehonden de groei in de Waddenzee afneemt. Er zijn indicaties dat de draagkracht van het gebied genaderd wordt, hoewel ook in 2017 het aantal pups weer toegenomen is. Voor de grijze zeehonden lijkt er voorlopig nog geen afremming van de groei te zijn. De getelde aantallen grijze zeehonden en het aantal getelde pups nemen nog steeds toe en de aantallen breiden zich uit naar het oosten.

De periode waarin de dieren verharen of jongen krijgen kan in de tijd verschuiven, waardoor het piekmoment gemist wordt. Dit kan een te laag geteld aantal opleveren. Periodiek extra tellingen zijn wenselijk om zo'n verschuiving te kunnen constateren en de monitoring er op aan te passen. De laatste keer is dit in 2014 gedaan.

De omvang van een populatie wordt bepaald door sturingsmechanismen zoals sterfte en geboorte, emigratie en immigratie. Natuurlijke factoren (aanwezigheid goede ligplaatsen, voedselbeschikbaarheid, ziekte) en maatschappelijke factoren (verstoring door recreatie, scheepvaart of andere activiteiten) beïnvloeden deze mechanismen. Er is nog weinig over bekend hoe al deze factoren van invloed zijn en daarmee de draagkracht bepalen: nader onderzoek is hiervoor nodig.

Opsplitsing van de Nederlandse Waddenzee in deelgebieden laat zien dat in sommige deelgebieden de laatste jaren de aantallen gewone en grijze zeehonden niet meer toenemen, terwijl in andere deelgebieden de aantallen juist wel toenemen. Mogelijke oorzaak van de stagnatie in bepaalde gebieden zou de toenemende verstoring door bijvoorbeeld recreatie kunnen zijn. Ook geomorfologische omstandigheden en de beschikbaarheid van voldoende voedsel kan de keuze voor een ligplaats bepalen. Om zicht te krijgen op het belang van voedselbeschikbaarheid helpt kennis over waar de zeehonden zich ophouden buiten de reguliere telperiodes.

Uit de vergelijking tussen de aantallen uit de verschillende deelgebieden blijkt dat tijdens de reproductieperiode vooral de deelgebieden in de oostelijke Waddenzee in trek zijn. In de verharingsperiode wordt juist vaker de voorkeur gegeven aan de ligplaatsen in de deelgebieden in de westelijke Waddenzee.

Onderzoek naar de factoren die de ligplaatskeuze van de zeehonden voor verharing en reproductie bepalen, zou de bescherming van de beide zeehondensoorten kunnen verbeteren en efficiënter maken. 



\section{Literatuur}

Aarts G, SMJM Brasseur, JJ Poos, J Schop, E Mul, T van Kooten, R Kirkwood, PJH Reijnders, AD Rijnsdorp \& I Tulp (In prep). The harbour seal as main top-predator of a coastal fish community.

Brasseur SMJM (2017). Seals in motion - How movements drive population development of harbour seals and grey seals in the North Sea. PhD Thesis, Wageningen University, Wageningen, The Netherlands.

Brasseur SMJM, J Creuwels van der Werf B \& Reijnders PJH (1996). Deprivation indicates necessity for haulout in harbor seals. Marine Mammal Science 12: 619-624.

Brasseur SMJM, JSM Cremer, EM Dijkman \& JP Verdaat (2013). Monitoring van gewone en grijze zeehonden in de Nederlandse Waddenzee; 2002 - 2012. Wageningen, Wettelijke Onderzoekstaken Natuur \& Milieu, WUR. WOt-werkdocument 352.

Brasseur SMJM, TD van Polanen Petel, T Gerrodette, HWG Meesters, PJH Reijnders \& G Aarts (2015). Rapid recovery of Dutch gray seal colonies fueled by immigration. Marine Mammal Science, Volume 31, issue 2, April 2015, pages 405-426.

Brasseur SMJM, PJH Reijnders, R Kirkwood \& G Aarts (2017a). Directional breeding migration in harbour seals in the Wadden Sea. (In: Brasseur 2017).

Brasseur SMJM, G Aarts, PJH Reijnders \& R Kirkwood (2017b). Grey seal tracking reveals different behaviours of resident and transient population components (In: Brasseur 2017).

Brasseur SMJM, R Czeck, A Galatius, LF Jensen, A Jess, P Korber, R Pund, U Siebert, J Teilmann \& S Klopper (2017c). Trilateral Seal Expert Group (TSEG). Grey Seal survey in the Wadden Sea and Helgoland in 2016-2017, General growth but local drop in numbers. Common Wadden Sea Secretariat (CWSS),

Brasseur SMJM, PJH Reijnders, JSM Cremer, HWG Meesters, R Kirkwood, LF Jensen, A Je $\beta$, A Galatius, J Teilmann \& G Aarts (2018). Echoes from the past: regional variations in recovery within a harbour seal population. PlosOne.

Daan N, H Gislason, J Pope \& J Rice (2005). Changes in the North Sea fish community: evidence of indirect effects of fishing? ICES J. Mar. Sci. 62: 177-188.

Galatius A, SMJM Brasseur, R Czeck, LF Jensen, A Je $\beta$, P Körber, R Pund, U Siebert, J Teilmann \& S Klöpper. (2015). Trilateral Seal Expert Group (TSEG). Aerial Surveys of Harbour Seals in the Wadden Sea in 2015. Moderate impact of the 2014 influenza epidemic. Common Wadden Sea Secretariat (CWSS).

Galatius A, SMJM Brasseur, R Czeck, LF Jensen, A Jeß, P Körber, R Pund, U Siebert, J Teilmann \& S Klöpper. (2016). Trilateral Seal Expert Group (TSEG). Aerial Surveys of Harbour Seals in the Wadden Sea in 2016. Population still in stagnation. Common Wadden Sea Secretariat (CWSS).

Galatius A, SMJM Brasseur, R Czeck, A Jeß, P Körber, R Pund, U Siebert, J Teilmann \& S Klöpper (2017). Trilateral Seal Expert Group (TSEG). Aerial Surveys of Harbour Seals in the Wadden Sea in 2017. Population counts still in stagnation, but more pups than ever. Common Wadden Sea Secretariat (CWSS).

Härkönen T \& KC Harding (2001). Spatial structure of harbour seal populations and the implications thereof. Canadian Journal of Zoology 79: 2115-2127.

Härkönen T, KC Harding \& MP Heide-Jorgensen (2002). Rates of increase in age-structured populations: a lesson from the European harbour seals. Canadian Journal of Zoology-Revue Canadienne De Zoologie 80: 1498-1510.

Härkönen TD, PJH Reijnders, J Teilmann, K Harding, A Hall, SMJM Brasseur, U Siebert, SJ Goodman, PD Jepson, T Dau Rasmussen \& D Thompson (2006). A review of the 1988 and 2002 phocine distemper virus epidemics in European harbour seals. Diseases of Aquatic Organisms.

Pomeroy PP, PR Redman \& SJS Ruddell, CD Duck \& SD Twiss (2005). Breeding site choice fails to explain interannual associations of female grey seals. Behavioral Ecology and Sociobiology 57: 546-556.

Reijnders PJH (1986). Reproductive failure in common seals feeding on fish from polluted coastal waters. Nature 324: 456-457. 
Reijnders PJH (1992). Retrospective Population Analysis and Related Future Management Perspectives for the Harbour Seal Phoca vitulina in the Wadden Sea. Netherlands Institute for Sea Research 20: 193-197.

Reijnders PJH, J van Dijk \& D Kuiper (1995). Recolonization of the Dutch Wadden Sea by the Grey Seal Halichoerus-Grypus. Biological Conservation 71: 231-235.

Reijnders PJH, SMJM Brasseur \& AG Brinkman (2003). The phocine distemper virus outbreak of 2002 amongst harbour seals in the North Sea and Baltic Sea: spatial and temporal development, and predicted population consequences. In: Wadden Sea Secretariat W, Germany. (ed) CWSS (eds), Management of North Sea harbour and grey seal populations. Proceedings of the International Symposium at EcoMare, Texel, The Netherlands, November 29-30, 2002. Wadden Sea Ecosystem, pp 19-25.

Reijnders PJH, SMJM Brasseur, HWG Meesters (2010). Earlier pupping in harbour seals, Phoca vitulina. Biology letters 6: 854-857.

Ries EH, LR Hiby \& PJH Reijnders (1998). Maximum likelihood population size estimation of harbour seals in the Dutch Wadden Sea based on a mark-recapture experiment. Journal of Applied Ecology 35: 332-339. 


\section{Verantwoording}

Het project zeehondenmonitoring is onderdeel van de Wettelijke Onderzoekstaken (WOT) Natuur \& Milieu, onderdeel Informatievoorziening Natuur, en wordt uitgevoerd in opdracht van het ministerie van Landbouw, Natuur en Voedselkwaliteit (LNV). Contactpersoon bij LNV voor de projecten die onder de Informatievoorziening Natuur vallen is Bernard Baerends. Contactpersoon bij de WOT Natuur \& Milieu, thema Informatievoorziening Natuur is Anne Schmidt van Wageningen Environmental Research.

Het rapport is beoordeeld door Oscar Bos (onderzoeker) en Jacob Asjes (manager integratie), beiden Wageningen Marine Research (WMR). Hun review heeft geleid tot verbeteringen van het document. 


\section{Verschenen documenten in de reeks Technical reports van de Wettelijke Onderzoekstaken Natuur}

\& Milieu vanaf 2016

WOt-technical reports zijn verkrijgbaar bij het secretariaat van Unit Wettelijke Onderzoekstaken Natuur \& Milieu te Wageningen. T 0317 - 4854 71; E info.wnm@wur.nl

WOt-technical reports zijn ook te downloaden via de website www.wur.nl/wotnatuurenmilieu

61 Berg, F. van den, A. Tiktak, J.J.T.I. Boesten \& A.M.A. van der Linden (2016). PEARL model for pesticide behaviour and emissions in soil-plant systems; Description of processes

62 Kuiters, A.T., G.A. de Groot, D.R. Lammertsma, H.A.H. Jansman \& J. Bovenschen (2016). Genetische monitoring van de Nederlandse otterpopulatie; Ontwikkeling van populatieomvang en genetische status 2014/2015

63 Smits, M.J.W., C.M. van der Heide, H. Dagevos, T. Selnes \& C.M. Goossen (2016). Natuurinclusief ondernemen: van koplopers naar mainstreaming?

64 Pouwels, P. , M. van Eupen, M.H.C. van Adrichem, B. de Knegt \& J.G.M. van der Greft (2016). MetaNatuurplanner v2.0. Status A

65 Broekmeyer, M.E.A. \& M.E. Sanders (2016) Natuurwetgeving en het omgevingsrecht. Achtergrond-document bij Balans van de Leefomgeving, 2014

66 Os, J. van, J. H.S.D. Naeff \& L.J.J. Jeurissen (2016).Geografisch informatiesysteem voor de emissieregistratie van landbouwbedrijven; GIABplus-bestand 2013 - Status A

67 Ingram, V.J., L.O. Judge, M. Luskova, S. van Berkum \& J. van den Berg (2016). Upscaling sustainability initiatives in international commodity chains; Examples from cocoa, coffee and soy value chains in the Netherlands.

68 Duin van W.E., H. Jongerius, A. Nicolai, J.J. Jongsma, A. Hendriks \& C. Sonneveld (2016). Friese en Groninger kwelderwerken: Monitoring en beheer 1960-2014.

69 Ehlert, P.A.I., T.A. van Dijk \& O. Oenema (2016). Opname van struviet als categorie in het Uitvoeringsbes/uit Meststoffenwet. Advies.

70 Ehlert, P.A.I., H.J. van Wijnen, J. Struijs, T.A. van Dijk, L. van Schöll, L.R.M. de Poorter (2016) Risicobeoordeling van contaminanten in afval- en reststoffen bestemd voor gebruik als covergistingsmateriaal

71 Commissie Deskundigen Meststoffenwet (2016). Protocol beoordeling stoffen Meststoffenwet. Versie 3.2

72 Kramer, H., J. Clement (2016). Basiskaart Natuur 2009. Een landsdekkend basisbestand voor de terrestrische natuur in Nederland

73 Dam, R.I. van, T.J.M. Mattijssen, J. Vader, A.E. Buijs \& J.L.M. Donders (2016). De betekenis van groene zelf-governance. Analyse van verschillende vormen van dynamiek in de praktijk.
74 Hennekens, S.M., M. Boss \& A.M. Schmidt (2016). Landelijke Vegetatie Databank; Technische documentatie, Status A

75 Knegt, B. de, et al. (2016). Kansenkaarten voor duurzaam benutten van Natuurlijk Kapitaal

76 Commissie Deskundigen Meststoffenwet (2016). Advies 'Mestverwerkingspercentages 2017'

77 W.H.J. Beltman, C. Vink \& A. Poot (2016). Calculation of exposure concentrations for $N L$ standard scenarios by the TOXSWA model; Use of FOCUS_TOXSWA 4.4.3 software for plant protection products and their metabolites in Dutch risk assessment for aquatic ecosystems

78 Koffijberg K., J.S.M. Cremer, P. de Boer, J. Postma \& K. Oosterbeek \& J.S.M. Cremer (2016). Broedsucces van kustbroedvogels in de Waddenzee in 2014.

79 Sanders, M.E. G.W.W Wamelink, R.M.A. Wegman \& J. Clement (2016). Voortgang realisatie nationaal natuurbeleid; Technische achtergronden van een aantal indicatoren uit de digitale Balans van de Leefomgeving 2016.

80 Vries, S. de \& I.G. Staritsky (2016). AVANAR 2.0 nader beschreven en toegelicht; Achtergronddocumentatie voor Status A.

81 Kuiters, A.T., G.A. de Groot, D.R. Lammertsma, H.A.H. Jansman \& J. Bovenschen (2016). Genetische monitoring van de Nederlandse otterpopulatie; Ontwikkeling van populatieomvang en genetische status 2015/ 2016.

82 Pleijte, M., R. Beunen \& R. During (2016). Rijksprojecten: hét natuurinclusieve werken? Een analyse van relaties tussen rijksprojecten en de Rijksnatuurvisie

83 Smits, M.J.W. en E.J. Bos (2016). Het stimuleren van ondernemen met natuur: handelingsopties voor de overheid

84 Horst, M.M.S. ter, W.H.J. Beltman \& F. van den Berg (2016). The TOXSWA model version 3.3 for pesticide behaviour in small surface waters; Description of processes

85 Mattijssen, T.J.M. (2016). Ideaaltypen en analysekader van groene burgerinitiatieven; Bijlage bij het rapport 'De betekenis van groene burgerinitiatieven: analyse van kenmerken en effecten van 264 initiatieven in Nederland

86 Wösten, J.H.M., F. de Vries \& J.G. Wesseling (2016). BOFEK2012 versie 2; Status $A$ 
87 Pleijte, M., R. During \& R. Michels (2016). Nationale parken in transitie; governance-implicaties van een veranderend beleidskader

88 Mol-Dijkstra, J.P.\& G.J Reinds (2017). Technical documentation of the soil model VSD+; Status $A$

89 Arets, E.J.M.M., J.W.H van der Kolk, G.M. Hengeveld, J.P. Lesschen, H. Kramer, P.J. Kuikman \& M.J. Schelhaas (2017). Greenhouse gas reporting for the LULUCF sector in the Netherlands. Methodological background, update 2016

90 Bruggen, C. van, A. Bannink, C.M. Groenestein, J.F.M. Huijsmans, H.H. Luesink, S.V. Oude Voshaar, S.M. van der Sluis, G.L. Velthof \& J. Vonk (2017). Emissies naar lucht uit de landbouw in 2014. Berekeningen met het model NEMA

91 Os van, J., M.G.T.M. Bartholomeus, L.J.J. Jeurissen \& C.G. van Reenen (2017). Rekenregels rundvee voor de landbouwtelling. Verantwoording van het gebruik van I\&R gegevens voor de landbouwtelling

92 Haas, W. de, R.J. Fontein \& M. Pleijte (2017). Is eenvoudig beter? Twee essays natuur en landschap in het nieuwe omgevingsbeleid

93 Schuiling, C., A.M. Schmidt, I.J. La Rivière \& R.A. Smidt (2017). Beschermde gebiedenregister; Technische documentatie, Status $A$.

94 Henkens, R.J.H.G., M.M.P. van Oorschot en J. Ganzevles (2017). Bijdrage van Green Deals aan de beleidsdoelen voor natuur en biodiversiteit

95 Arets, E.J.M.M., J.W.H van der Kolk, G.M. Hengeveld, J.P. Lesschen, H. Kramer, P.J. Kuikman \& M.J. Schelhaas (2017). Greenhouse gas reporting for the LULUCF sector in the Netherlands. Methodological background, update 2017

96 IJsseldijk, L.L., M.J.L. Kik, L. Solé \& A. Gröne (2017). Postmortaal onderzoek van bruinvissen (Phocoena phocoena) uit Nederlandse wateren, 2016.

97 Verburg, R.W., W.H.G.J. Hennen, L.F. Puister, R. Michels \& K. van Duijvendijk (2017). Estimating costs of nature management in the European Union; Exploration modelling for PBL's Nature Outlook

98 Bruggen, C. van, A. Bannink, C.M. Groenestein, J.F.M. Huijsmans, H.H. Luesink, S.V. Oude Voshaar, S.M. van der Sluis, G.L. Velthof \& J. Vonk (2017). Emissies naar lucht uit de landbouw in 2015. Berekeningen met het model NEMA

99 Kuiters, A.T., G.A. de Groot, D.R. Lammertsma, H.A.H. Jansman \& J. Bovenschen (2017). Genetische monitoring van de Nederlandse otterpopulatie; Ontwikkeling van populatieomvang en genetische status 2016/2017

100 Adriaanse, P.I. \& W.H.J Beltman (2017) Comparison of pesticide concentrations at drinking water abstraction points in The Netherlands simulated by DROPLET version 1.2 and 2.0

101 Daamen, W.P., A.P.P.M. Clerkx \& M.J. Schelhaas (2017). Veldinstructie Zevende Nederlandse Bosinventarisatie (2017-2021).
102 Boer, T.A. de \& F.L. Langers (2017). Maatschappelijk draagvlak voor natuurbeleid en betrokkenheid bij natuur

103 Buijs, A.E., B.H.M. Elands \& C.S.A. van Koppen (2017) 25 jaar burgerbetrokkenheid in het natuurbeleid. Analyse van beleidsdiscoursen en publiek draagvlak

104 Cremer, J.S.M., S.M.J.M. Brasseur., A. Meijboom, J. Schop \& J.P. Verdaat (2017). Monitoring van gewone en grijze zeehonden in de Nederlandse Waddenzee, 2002-2017

105 Glorius, S.T., A. Meijboom, J.T. van der Wal \& J.S.M. Cremer (2017). Ontwikkeling van enkele mosselbanken in de Nederlandse Waddenzee, situatie 2016

106 Hennekens, S.M., W.A. Ozinga \& J.H.J. Schaminée (2017). BioScore 3 - Plants. Background and preprocessing of distribution data

107 Melman, Th.C.P., M.H.C. van Adrichem, M. Broekmeyer, J. Clement, R. Jochem, H.A.M. Meeuwsen, F.G.W.A. Ottburg, A.G.M. Schotman \& T. Visser (2017). Bijdrage natuurcombinaties aan landelijke natuurdoelstelling buiten NNN; Verkenning van een methodiek, gebaseerd op ecologische modellen

109 Overbeek, M.M.M., E. Smeets \& D. Verhoog (2017). Biobased materialen, circulaire economie en natuurlijk kapitaal. 



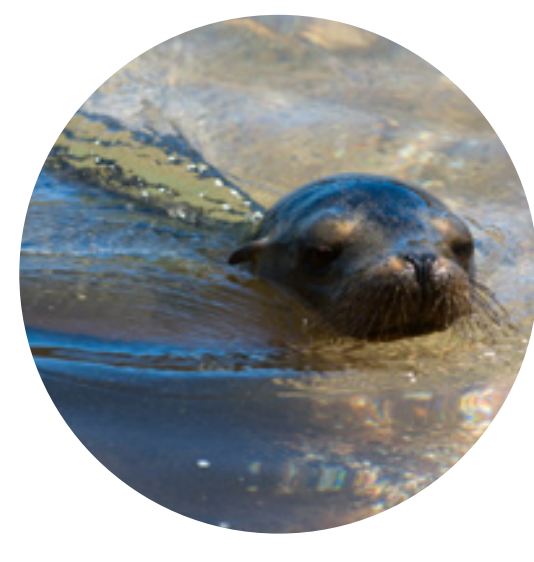

Thema Informatievoorziening Natuur Wettelijke Onderzoekstaken Natuur \& Milieu

P.O. Box 47

6700 AA Wageningen

T (0317) 485471

E info.wnm@wur.nl

ISSN 2352-2739

www.wur.nl/wotnatuurenmilieu

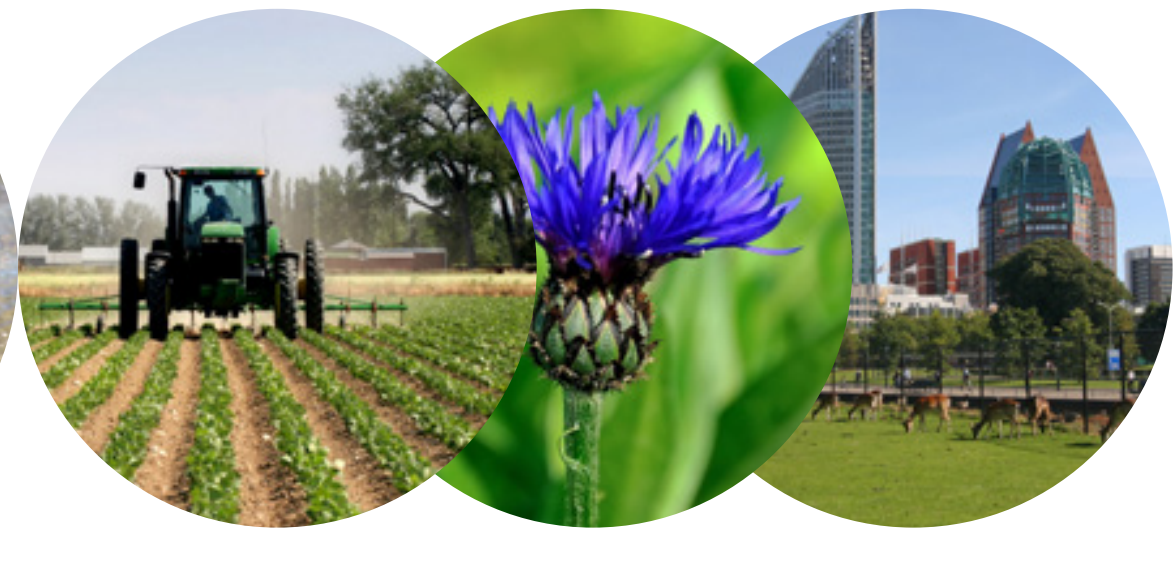

The mission of Wageningen University and Research is "To explore the potential of nature to improve the quality of life". Under the banner Wageningen University \& Research, Wageningen University and the specialised research institutes of the Wageningen Research Foundation have joined forces in contributing to finding solutions to important questions in the domain of healthy food and living environment. With its roughly 30 branches, 5,000 employees and 10,000 students, Wageningen University \& Research is one of the leading organisations in its domain. The unique Wageningen approach lies in its integrated approach to issues and the collaboration between different disciplines.

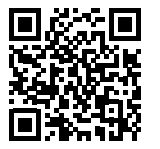

